\title{
Institutions and Corporate Investment: Evidence from Investment-Implied Return on Capital in China*
}

\author{
Qiao Liu ${ }^{\dagger}$ \\ University of Hong Kong \\ Alan Siu $\ddagger$ \\ University of Hong Kong
}

This Draft: September 2010

\begin{abstract}
We assess the impact of institutions on Chinese firms' corporate investment in an investment Euler equation framework. We allow the variables measuring institutions to affect the rate at which firm managers discount future investment payoffs. Applying generalized method of moments estimators to large samples of Chinese firms, we estimate the stochastic discount rates derived from actual investment and examine how they vary across institutional variables. We document robust evidence that ownership is the primary institutional factor affecting corporate investment in China. The derived discount rate for a non-state firm is approximately 10 percentage points higher than that of an otherwise equal state firm. State firms tend to use higher discount rates to invest after they are partially privatized. We also find that firms with higher levels of corporate governance use higher discount rates to make investment.
\end{abstract}

JEL Classification: G31; G34; G18; D21; O16

Keywords: Institutions, investment Euler equation, investment-implied discount rate, corporate governance, Chinese economy

${ }^{*}$ We are grateful to an anonymous referee for many constructive suggestions that have greatly improved the paper. We thank Toni Whited for kindly sharing programming codes and offering computation suggestions. We also thank Hongbin Cai, Joseph Fan, Qiang Kang, Hongbin Li, Wing Suen, Chenggang Xu, Charles Leung, Yong Wang, Guofu Zhou, and seminar participants at Keio University, Beijing University, University of Hong Kong, Chinese University of Hong Kong, City University of Hong Kong, Tsinghua University, the Central University of Finance and Economics, and the 2007 China International Conference in Finance (CICF) for useful comments, and Yong Wei for able research assistance. Financial support from the University Grants Committee of the Hong Kong Special Administrative Region, China (Projects No. AOE/H-05/99, HKU7472/06H, and HKU747107H) are gratefully acknowledged. All errors remain our own responsibility.

${ }^{\dagger}$ Corresponding author. School of Economics and Finance, University of Hong Kong, Hong Kong. Phone: (852) 2859 1059. Fax: (852) 2548 1152. E-mail: qliu@hku.hk.

${ }^{\ddagger}$ School of Economics and Finance, University of Hong Kong, Hong Kong. Phone: (852) 2857 8505. Fax: (852) 2548 1152. E-mail: asiu@econ.hku.hk. 


\title{
Institutions and Corporate Investment: Evidence from Investment-Implied Return on Capital in China
}

\begin{abstract}
We assess the impact of institutions on Chinese firms' corporate investment in an investment Euler equation framework. We allow the variables measuring institutions to affect the rate at which firm managers discount future investment payoffs. Applying generalized method of moments estimators to large samples of Chinese firms, we estimate the stochastic discount rates derived from actual investment and examine how they vary across institutional variables. We document robust evidence that ownership is the primary institutional factor affecting corporate investment in China. The derived discount rate for a non-state firm is approximately 10 percentage points higher than that of an otherwise equal state firm. State firms tend to use higher discount rates to invest after they are partially privatized. We also find that firms with higher levels of corporate governance use higher discount rates to make investment.
\end{abstract}

JEL Classification: G31; G34; G18; D21; O16

Keywords: Institutions, investment Euler equation, investment-implied discount rate, corporate governance, Chinese economy 


\section{Introduction}

A large and growing literature investigates the effects of institutions on economic performance and finds that good institutions promote economic development. ${ }^{1}$ Much of this literature is based on cross-country studies that are likely subject to contamination due to country differences in accounting standards, taxation, and bankruptcy laws. This literature also fails to account for obvious outliers such as China - the unprecedented economic growth over the past three decades in China has been based largely on weak institutions and inefficient financial intermediation (Allen, Qian and Qian, 2005). In this paper, we use an investment Euler equation framework to examine the extent to which institutions affect Chinese firms' investment behavior. Applying generalized method of moments (GMM) estimators to large samples of Chinese industrial firms, we estimate the rates these firms use to discount future investment payoffs. We then examine how this investment-implied return on capital or discount rate varies across variables measuring institutions. We document robust evidence that ownership is the primary institutional factor affecting firm-level return on capital in China. The investment-implied return on capital for a non-state firm is approximately 10 percentage points higher than that of an otherwise equal state firm. We also find that state firms use higher discount rates to invest after they are partially privatized and that firms with better corporate governance have a higher return on capital.

The motivations for our inquiry are three fold. First, there is little empirical evidence at the micro level on the dynamic relation between corporate investment and institutions. For instance, while heavy investment and exports have long been viewed as two pillars of China's economic ascendancy, few studies examine how institutional factors shape Chinese firms' investment behavior. We contribute to this line of research by presenting evidence from large samples of Chinese industrial firms. Second, extant studies rely largely on cross-country analysis and reduced-form regressions. Drawing clean inferences from these studies might be

\footnotetext{
${ }^{1}$ See, e.g., Acemoglu, Johnson and Robinson, 2001; Claessens and Laeven, 2003; Levine and Zervos, 1998; Rajan and Zingales, 1998; and Bekaert, Harvey, and Lundblad, 2005.
} 
difficult as they are unavoidably plagued by endogeneity. By estimating a structural model of corporate investment, we potentially mitigate this concern. Third, in our structural setting, the effects of institutions on corporate investment are readily captured by the stochastic discount rates inferred from actual corporate investment. This investment-implied return on capital reveals firm managers' true propensity to investment and can be interpreted in an intuitive way. In addition, our approach is not restricted to publicly listed firms, and imposes minimal requirements on capital market information, and thus may be useful for research on emerging markets, where capital markets are under-developed and financial disclosure is limited and less transparent.

We begin by constructing a standard intertemporal investment model that characterizes the investment allocation of a utility-maximizing firm manager. The manager maximizes utility by choosing how much income to consume and how much income to invest in each period. Dividend consumption is constrained by the firm's profit function and the manager's investment decision. The manager chooses the optimal level of investment so as to be indifferent between investing today and investing tomorrow. The model produces results in terms of intertemporal investment substitution where the stochastic discount factor is related to the manager's risk preference - a lower discount factor (a higher discount rate) corresponds to a more cautious attitude toward corporate investment. The model allows firm managers' discount rates to vary across variables measuring institutions. The effects of institutions on corporate investment are thus captured by the differences in discount rates that firm managers use to make investment decisions.

The intuition for using an investment Euler equation to assess the effect of institutions on corporate investment is easiest to see in a simple two-period example. When a firm manager considers investing today versus tomorrow, he has to consider the costs and benefits of this decision. Investing today entails a cost today whereas investing tomorrow defers the cost until later and thus reduces this cost in terms of its present value. However, investing tomorrow entails forgoing the marginal product of capital for one period. An investment 
Euler equation is simply a first-order condition that equates the marginal cost of investing today and the expected discounted cost of investing tomorrow. In this setting, the discount rate characterizes the manager's willingness to invest. If the manager becomes more cautious or less willing to embark on new and risky projects, this increased caution will be reflected as an increase in the discount rate.

We expect that all else being equal, the discount rates used by managers of state owned enterprises (SOEs hereafter) to discount future investment payoffs are lower than those used by managers of other types of firms. Denoting the discount rate for an SOE as $r^{S O E}$ and the discount rate for other types of firms as $r$, we conjecture that $r=r^{S O E}+\theta$. In the Chinese context, $\theta$ is likely to be greater than 0 for two reasons. First, due to their soft budget constraints, SOEs are afflicted with an "investment hunger" problem (see, e.g., Kornai, 1980); they demonstrate stronger preference for investment, and adopt relatively lower discount rates. Over-investment is thus more likely to be a concern among SOEs. Second, non-state firms, especially private firms, are exposed to a variety of institutional constraints (e.g., policy and tax distortions and expropriation by the government), and hence may be more cautious about investment.

Notably, a positive $\theta$ may also result from a high level of financing constraints facing non-state firms simply because these firms are not favored by the state-dominated financial system. Institutional deficiencies and financing constraints interact to affect corporate investment in China. While our empirical strategy centers on exploring the magnitude and distribution of $\theta$, it cannot disentangle the impact of external financing constraints from that of institutions. However, we believe that a positive $\theta$ is mainly driven by institutional deficiencies for three reasons. First, asymmetric access to finance is itself a reflection of poor institutions (i.e., lack of a level playing ground). Second, when we compare SOEs to mixed-ownership firms, the majority of which are former SOEs that are still controlled by the state, we find that while the mixed firms display no significant difference in their access 
to external finance, their $\theta$ is significantly positive. ${ }^{2}$ Third, we find similar results when we apply the same approach to the privatized SOEs and the listed firms in China, which are less subject to external financing constraints.

Our empirical analysis formalizes the above intuition. The Euler equation governs the manager's decision on how much to invest. The Markovian nature of our model reduces the manager's infinite-horizon dynamic problem to an optimality condition concerning investment this period versus next period. The effects of institutions on corporate investment are captured by $\theta$, which is closely related to institutional variables such as ownership. It is possible to identify these effects from the cross-sectional variation in corporate investment. Further, after controlling for a measure of investment opportunity (i.e., capital productivity), we can identify whether cross-sectional variation in investment is caused by differences in the stochastic discount rate or differences in productivity, which alleviates the endogeneity concern that arises in a reduced-form regression framework. We interpret higher discount rates among well-governed firms as evidence that good institutions mitigate over-investment. Alternatively, one may argue that imposing higher discount rates may delay or deter valuable investments, potentially causing under-investment. While we cannot completely rule out this possibility, we believe that it is less a concern. Throughout our empirical analysis, we control for investment opportunities and other firm-specific variables, and thus systematic differences in discount rates most likely reflect the effects of institutions. Moreover, given that overinvestment and in turn over-capacity have been the primary structural problems challenging the Chinese economy, little anecdotal and empirical evidence shows that under-investment is a pervasive concern in the absence of external financing constraints.

We estimate our investment Euler equation using generalized method of moments (GMM) estimators. A key advantage of this approach is that it avoids sample selection, simultaneity, and measurement error biases via structural estimation with a large dataset. Using actual

\footnotetext{
${ }^{2}$ The difference between SOEs' and other types of firms' discount rates, $\theta$, may also capture the effects of factors other than institutional deficiencies on corporate investment, e.g., irrational decision making by firm managers, etc. However, these factors are likely to be firm-specific and their effects likely average out when aggregating.
} 
corporate investment data retrieved from a well-maintained dataset developed by the National Bureau of Statistics of China (NBS), we apply GMM estimators to a panel of 36,103 industrial firms from 2000 to 2005 . We parameterize the stochastic discount factor as a linear function of variables measuring institutions and firm-specific characteristics. Based on the estimated structural parameter values, we compute the "implied" return on capital or discount rate and examine its distribution. The estimates of our model yield several principal findings. First, we find that the inferred discount rate varies significantly across ownership. In our benchmark estimation, the inferred return on capital for a private firm, a Hong Kong, Macao, or Taiwan invested firm (HK/TW firm), a foreign firm, a mixed firm (i.e., joint stock firm), and a collective firm is respectively 9.4,11.9. 10, 13, and 11.4 percentage points higher than that of an otherwise equal SOE. Second, we find that the ownership effect is robust to controlling or industries and the level of regional institutions and financial development, indicating that ownership is the primary institutional factor affecting corporate investment in China.

To shed further light on the effects of institutions on corporate investment, we apply the same GMM estimators to another two samples of Chinese firms, the SOEs that were partially privatized during our sample period and the universe of Chinese listed firms. Firms in these two samples are less subject to external financing constraints and a positive $\theta$ is more likely to be driven by institutions rather than financing constraints. Our GMM estimations on the two samples yield very similar results. In particular, we find that an SOE tends to use a higher discount rate to invest after it has changed its ownership status from SOE to mixed. We also find that all else being equal, a state-control listed firm has an implied return on capital that is 15.8 percentage points lower than that of an otherwise equal listed firm. In addition, we provide evidence that firms with a larger fraction of outside board members, firms with more shares held by a controlling shareholder, and firms with $\mathrm{H}-$ or $\mathrm{B}-$ shares traded by foreign investors have a higher return on capital. Well-governed firms in China are more cautious about investment and are less subject to the over-investment problem. 
Overall, we contribute to the literature on corporate investment and institutions. Different from Dwenter and Malatesta (2001), Love (2003), and Wurgler (2000), we focus on a single country and use more detailed firm-level data, which allows us to construct a richer set of variables in examining the factors affecting corporate investment and to better control for potential contamination due to cross-country differences. Moreover, we study the case of China, which is of particular interest not only because of its size, but also because it is an obvious outlier in most cross-country studies on the relation between institutions and economic performance. While fixed asset investment remains one of the most significant pillars of China's economic growth, little research examines corporate investment and the underlying economic and institutional factors that shape corporate investment behavior. Deriving firm level returns on capital from actual capital expenditures and mapping out their various cross-sections help us better understand corporate investment in China.

We also contribute to a small but growing literature on investment efficiency and resource mis-allocation in China. Bai, Hsieh, and Qian (2006) use aggregate data to estimate return to capital in China. However, using aggregate data cannot directly measure the extent of capital mis-allocation and link corporate investment behavior to institutional factors. Hsieh and Klenow (2007) provide evidence of sizable gaps in the returns to capital across firms within the same sectors in China and India compared to the U.S. But they do not investigate systematically how the mis-allocation of capital is related to institutions. Dollar and Wei (2007) examine how institutions such as ownership and regional economic development affect corporate investment efficiency. But they use reduced-form model specifications based on a small sample of survey data, and their measure of investment efficiency - the observed average revenue product of capital - captures operating performance rather than ex ante managerial investment propensity. Moreover, to argue that institutions enhance investment efficiency at the micro level requires identifying firms that "should" be growing given their investment opportunities.

We additionally contribute to the investment Euler equation literature (see, e.g., 
Whited, 1992; Forbes, 2007; Love, 2003; Chirinko and Schaller, 2004; and Whited and $\mathrm{Wu}, 2006)$ and to the investment-based asset pricing literature, which explains the crosssection of expected stock returns or costs of equity from the perspective of value-maximizing firms (see, e.g., Cochrane, 1991; Zhang, 2005; and Liu, Whited, and Zhang, 2009). Liu, Whited, and Zhang (2009) use investment Euler equations to derive cross-sectional expected stock returns, which are essentially levered investment returns tied to firm characteristics. Our use of investment Euler equations focuses instead on the effects of institutional variables on corporate investment via the discount rates perceived by firm managers. Our paper thus is similar in spirit to Kang, Liu, and Qi (2010), who apply an investment Euler equation framework to examine how government regulations (the Sarbanes-Oxley Act) affect firm investment in the U.S.

The rest of the paper proceeds as follows. Section 2 discusses the institutional background

in China and related literature, and presents four hypotheses on the potential effects of China-specific institutions on corporate investment. Section 3 provides an investment model and describes our estimation strategy. Section 4 discusses the data and variables used in our empirical analysis. In Section 5, we discuss the effect of ownership on corporate investment, and in Section 6 we estimate our model for the privatized SOEs and the Chinese listed firms, respectively. Finally, we conclude the paper in Section 7.

\section{Institutional Background and Corporate Investment in China}

China's striking economic growth over the past three decades has been driven largely by fixed asset investment. As evidenced by the most recent global economic crisis, when China's exports experienced a significant drop as a result of weak demand in the developed economies, investment became the single most important pillar to sustain China's growth. Two distinct features characterize fixed asset investment during China's reform era. First, the rate of 
fixed asset investment has hovered at a high level, partly due to a high domestic savings ratio and China's success in attracting foreign direct investment (FDI). As shown in Table A1, fixed asset investment accounts for nearly $50 \%$ of China's GDP, which from time to time raises the concern that the Chinese economy is overheating due to over-investment. Second, as shown in Table A2, more than $50 \%$ of fixed asset investment concentrates in the state sector or the quasi-state sector, where productivity and investment efficiency are believed to be considerably low.

The excessive amount of capital allocated to the state sector results in widespread inefficiency among SOEs, reduced overall productivity of the economy, and a large amount of non-performing loans. ${ }^{3}$ Prior literature has identified several sources of inefficiency in corporate investment, and attributes these sources to insufficient or weak institutions and inefficient financial intermediation. First, during the reform era, China can be described as a de facto federalism, with local governments having significant autonomy in economic matters (Qian and Xu, 1993). Local bureaucrats are assessed and promoted primarily based on local economic growth driven by investment. Returns generated by investment help pay for social spending on everything from education to health care - costs that are now the local governments' responsibility. Local officials therefore have strong incentives to approve new projects to stimulate economic growth. A large number of such investments have been labeled "image" projects (projects undertaken by local governments to boost their local image) or "political achievement" projects (projects undertaken to boost local bureaucrats' scores on key performance indicators), and inherently suffer from dim earnings prospects. From time to time, the central government has to take a slew of measures such as raising bank lending rate and/or bank reserve requirements, and sometimes outright administrative methods to put the brakes on investment boom to ensure that overheated investment does not lead to inflation and a pile-up of bad loans. ${ }^{4}$

\footnotetext{
${ }^{3}$ As Farrell et al. (2006) show, during the first half of the 1990s, $\$ 3.30$ of investment was needed to produce $\$ 1.00$ of GDP growth in China. Since 2001, $\$ 1.00$ of GDP growth has required $\$ 4.90$ of new investment $40 \%$ higher than the amount required in South Korea and Japan during their higher-growth periods.

${ }^{4}$ One recent example occurred in August 2006, when the governor of Inner Mongolia and his two
} 
Second, the state-dominated financial system in China has systematically allocated capital away from more productive sectors/regions toward less effective sectors/regions (see, e.g., Young, 2001; Brandt and Li, 2003; Cull and Xu, 2003; and Boyreau-Debray and Wei, 2005). Because of their soft budget constraints, SOEs are afflicted with a pervasive "investment hunger" problem and are prone to over-investing regardless of the demand for their products (Kornai, 1980). Legally and financially, inefficient SOEs are favored at the expense of more efficient non-state sectors (Huang, 2003).

Despite numerous anecdotes and sound economic intuition, it remains empirically difficult to map out the dynamic relation between corporate investment and institutions. In this paper we propose a new empirical approach and provide direct evidence on Chinese firms' corporate investment. Using actual corporate investment data, we estimate investment Euler equations that characterize Chinese firms' investment behavior to derive the effective discount rate perceived by firm managers in making investment spending decisions. This implied return on capital is similar to the managerial hurdle rate, and is potentially a function of variables measuring institutions.

The soft budget constraints afflicting SOEs and the fact that local governments act as decision makers suggest that SOEs may demonstrate stronger investment propensity and hence adopt lower discount rates: SOEs are favored by the state (e.g., they are less subject to regulatory burdens, insecure property rights, and credit constraints), and thus they are likely to perceive lower costs of capital. Non-state sectors, in contrast, are exposed to a variety of institutional constraints, and are more likely to adopt higher hurdle rates to make investment. Using the notation introduced earlier, we therefore argue that $r^{S O E}$ is a distorted reflection of the market price of capital, in particular, it tends to be lower than the market rate, and that the gap between $r^{S O E}$ and $r$ is likely to be positive and persistent. We thus lieutenants were publicly criticized by the State Council for disobeying the central government's call to slow investment by allowing hundreds of millions of dollars of investment in coal-burning power plants. This investment boosted local economic growth but has been associated with ever-worsening environmental problems in the northern part of China, several fatal accidents, and low efficiency (source: the Wall Street Journal - Asia Edition, August 18, 2006). 
have the following hypothesis:

H1: The implied return on capital derived from actual investment is lower for SOEs and higher for non-state firms (i.e., collective firms, private firms, $H K / T W$ firms, and foreign firms.)

We next conjecture that product market competition affects corporate investment behavior as well. Intuitively, firms in a more competitive market likely face greater pressure from their rivals and hence are more cautious in making investment decisions. The impact of competition on corporate investment could be much more involved, however. Taking into account the fact that firms' options exercise strategies are formed strategically as part of a Nash equilibrium (i.e., are not formulated in isolation), several studies (e.g., Grenadier, 1996, 2002; and Williams, 1993) show that an increase in competition leads to earlier exercise of options. In the context of real-world corporate investment, the playing of a strategic exercise game implies that an increase in competition may actually speed up investment. ${ }^{5}$ We thus expect a negative effect of competition on discount rates.

In addition, given significant cross-regional variation in the quality of institutions, we expect the implied return on capital to be higher for firms located in regions with better institutions and a more market-oriented financial system. ${ }^{6}$ Combining the competition and regional institution factors, we have:

H2: The implied return on capital derived from actual investment is higher for firms operating in a less competitive market and for firms located in regions with better institutions and a more market-oriented financial system.

Note that a caution has to be taken here because both competition and regional institutions are highly correlated with the presence of state ownership. Their effects on implied return on capital may therefore be camouflaged by the ownership effect.

\footnotetext{
${ }^{5} \mathrm{We}$ are grateful to an anonymous referee for pointing out this explanation and its ensuing insight.

${ }^{6}$ Using Italian data, Guiso, Sapiegza, and Zingales (2004) document that local financial development enhances the probability that an individual starts his own business, favors entry of new firms, increases competition, and promotes growth. Local financial development is an important determinant of the economic success of an area.
} 
If institutions affect corporate investment, firms' investment decisions should be different once the institutions concerning firms have been improved. The on-going privatization wave in China provides us with an opportunity to examine how changes in institutions affect corporate investment decisions. Converting SOEs to joint stock companies (i.e., mixedownership companies) has been the common privatization route in China. The conversion may takes many forms. Selling part of the shares to non-state shareholders and even the public via initial public offerings (IPOs) is the common practice. We conjecture that an SOE's investment will be improved after it changes its ownership status from SOE to mixed. We have:

H3: The SOEs' implied return on capital increases after they have been partially privatized.

While we argue that the sign and magnitude of $\theta$ capture differences in corporate investment caused by institutional deficiencies, a positive $\theta$ may also result from a high level of financing constraints faced by non-state firms simply because these firms are not favored by the state-dominated financial system. Testing $H 3$ above may help to disentangle the impact of external financing constraints from the impact of institutions because the majority of privatized SOEs are still state controlled.

In the same vein, we apply the same estimators to the universe of China's listed firms, among which external financing constraints are less severe. We expect that all else being equal, firms with better corporate governance tend to be more cautious about investment. Evidence from the sample of Chinese listed firms should more likely reflect differences in corporate investment behavior caused by institutions. We have:

H4: All else being equal, the implied return on capital is higher for firms with better corporate governance. 


\section{Model and Estimation Strategy}

To motivate our empirical work and provide guidance on the choice of control variables in the estimation, we offer a simple partial-equilibrium model in which a firm manager maximizes expected utility by choosing investment and consumption. We derive our investment Euler equation from this simple model. We then outline the framework for our empirical analysis.

\subsection{A Simple Model}

Consider an infinitely lived firm $i$ that uses capital to produce goods in each period $t$. The firm manager maximizes the expected present discounted value of his utility over an infinite horizon,

$$
V_{i 0}=E_{i 0}\left[\sum_{t}^{\infty} \beta u\left(d_{i t}\right)\right],
$$

where $E_{i 0}$ is the expectations operator conditional on the manager's time 0 information set; $\beta$ is the one-period discount factor common to all firms; $u($.$) is the manager's utility function$ (if the manager is risk-averse, the utility function is concave); and $d_{i t}$ is the dividend paid by firm $i$ in period $t$.

The manager maximizes Equation (1) subject to two conditions. The first defines dividends,

$$
d_{i t}=\Pi\left(K_{i t}, \zeta_{i t}\right)-C\left(I_{i t}, K_{i t}\right)-I_{i t}
$$

where $K_{i t}$ is the beginning-of-period capital stock; $\zeta_{i t}$ is a shock to the profit function that follows a Markov process and is observed by the firm at time $t ; \Pi\left(K_{i t}, \zeta_{i t}\right)$ is the firm's profit function with $\Pi_{K} \equiv \frac{\partial \Pi}{\partial K}>0 ; I_{i t}$ is investment during time t; and $C\left(I_{i t}, K_{i t}\right)$ is the real cost of adjusting the capital stock, with $\frac{\partial C}{\partial I}>0, \frac{\partial C}{\partial K}<0$, and $\frac{\partial^{2} C}{\partial I^{2}}>0$.

The second condition characterizes capital stock accumulation,

$$
K_{i t+1}=\left(1-\delta_{i}\right) K_{i t}+I_{i t}
$$


where $\delta_{i}$ is the firm-specific constant rate of economic depreciation.

The choice variables in this model are $I_{i t}$ and $d_{i t}$, and the state variable is $K_{i t}$. Solving the model yields the Euler condition for $K_{i t}$ :

$$
1+\left(\frac{\partial C}{\partial I}\right)_{i t}=E_{i t}\left[\beta \frac{u^{\prime}\left(d_{i t+1}\right)}{u^{\prime}\left(d_{i t}\right)}\left\{\left(\frac{\partial \Pi}{\partial K}\right)_{i t+1}-\left(\frac{\partial C}{\partial K}\right)_{i t+1}+\left(1-\delta_{i}\right)\left(1+\left(\frac{\partial C}{\partial I}\right)_{i t+1}\right)\right\}\right]
$$

where $\frac{\partial C}{\partial I}$ is the marginal adjustment cost of investment; $\beta \frac{u^{\prime}\left(d_{i t+1}\right)}{u^{\prime}\left(d_{i t}\right)}$ is the marginal rate of substitution of dividends, or the pricing kernel from a consumption-based asset pricing model; and $\frac{\partial \Pi}{\partial K}$ is the marginal profit of capital. For notational convenience, we define $\Gamma_{i t+1} \equiv \beta \frac{u^{\prime}\left(d_{i t+1}\right)}{u^{\prime}\left(d_{i t}\right)}$. We immediately rewrite Equation (4) as follows:

$$
1+\left(\frac{\partial C}{\partial I}\right)_{i t}=E_{i t}\left[\Gamma_{i t+1}\left\{\left(\frac{\partial \Pi}{\partial K}\right)_{i t+1}-\left(\frac{\partial C}{\partial K}\right)_{i t+1}+\left(1-\delta_{i}\right)\left(1+\left(\frac{\partial C}{\partial I}\right)_{i t+1}\right)\right\}\right]
$$

The Euler equation in Equation (5) describes the evolution of the firm manager's investment decisions along the optimal path and has an intuitive interpretation. To decide whether to invest in the current period versus in the next period, a manager must consider the costs and benefits of the timing decision. This equation is simply a first-order condition that describes the optimal intertemporal allocation of investment. The left-hand side represents the marginal adjustment cost of investing in this period. The right-hand side represents the expected discounted cost of deferring investment to next period, which consists of the marginal product of capital and the marginal reduction in adjustment costs from an increment to the capital stock. Notice that even if the firm waits, it still incurs adjustment costs. Optimizing investment necessitates that, on the margin, the manager must be indifferent between investing in the current period and transferring those resources to the next period.

The factor $\Gamma_{i t+1}$ in Equation (5) merits further discussion. By construction, $\Gamma_{i t+1}$ is the product of the discount factor common to all firms $(\beta)$ and the ratio of the marginal utility of dividends in the next period to the marginal utility of dividends in the current 
period. Because our investment Euler equation characterizes the optimal intertemporal allocation of investment, $\Gamma_{i t+1}$ is essentially the discount factor that the firm manager uses to discount the investment returns in the next period. While $\Gamma_{i t+1}$ is clearly related to the manager's preferences, it can be interpreted as the stochastic discount factor of the dynamic utility optimization problem that guides the manager's optimal investment choices. We can accordingly define the stochastic discount rate $r_{i t}$ as

$$
r_{i t}=\frac{1}{\Gamma_{i t}}-1
$$

where $r_{i t}$ can be interpreted as the "perceived" hurdle rate the firm manager uses for optimal investment. Note that if the firm manager is risk-averse and dividend growth is positive, greater managerial risk aversion implies a higher discount rate (Cochrane, 2001, pp. 13-14).

\subsection{Estimation}

To estimate the model, we use the assumption of rational expectations to replace the expectations operator in Equation (5) with an expectational error, $e_{i t+1}$, where $E_{i t}\left(e_{i t+1}\right)=0$ and $E_{i t}\left(e_{i t+1}^{2}\right)=\sigma_{i t}^{2}$. The first condition suggests that $e_{i t+1}$ is uncorrelated with the information available at time $t$, and the second implies that the expectational error can be heteroskedastic. We can thus rewrite Equation (5) as

$$
\Gamma_{i t+1}\left\{\left(\frac{\partial \Pi}{\partial K}\right)_{i t+1}-\left(\frac{\partial C}{\partial K}\right)_{i t+1}+\left(1-\delta_{i}\right)\left(1+\left(\frac{\partial C}{\partial I}\right)_{i t+1}\right)\right\}=1+\left(\frac{\partial C}{\partial I}\right)_{i t}+e_{i t+1}
$$

To parameterize the marginal product of capital, we follow Whited (1998) and Whited and $\mathrm{Wu}(2006)$ and assume that firms are imperfectly competitive. We thus set the output price as a constant markup, $\mu$, over the marginal cost. In this case, constant returns to scale implies

$$
\frac{\partial \Pi}{\partial K}\left(K_{i t}, \zeta_{i t}\right)=\frac{Y_{i t}-\mu V C_{i t}}{K_{i t}}
$$


where $Y_{i t}$ is output; $\mu$ is the markup; $V C_{i t}$ is variable cost; and $K_{i t}$ is capital stock.

Firms incur adjustment costs when investing. The adjustment cost function is increasing and convex in $I_{i t}$ and decreasing in $K_{i t}$. We use a standard quadratic function form to specify the adjustment cost function, $C\left(I_{i t}, K_{i t}\right)$, as follows: ${ }^{7}$

$$
C\left(I_{i t}, K_{i t}\right)=\left(\frac{\alpha}{2}\right)\left(\frac{I_{i t}}{K_{i t}}\right)^{2} K_{i t}
$$

where $\alpha$ is the adjustment cost parameter to be estimated.

Substituting Equation (8) into Equation (7), differentiating Equation (9) with respect to $I_{i t}$ and $K_{i t}$, and substituting the derivatives into Equation (7), we obtain the following equation:

$$
\Gamma_{i t+1}\left\{\frac{Y_{i t+1}-\mu V C_{i t+1}}{K_{i t+1}}+\frac{\alpha}{2}\left(\frac{I_{i t+1}}{K_{i t+1}}\right)^{2}+\left(1-\delta_{i}\right)\left(1+\alpha \frac{I_{i t+1}}{K_{i t+1}}\right)\right\}=1+\alpha \frac{I_{i t}}{K_{i t}}+e_{i t+1} .
$$

To estimate Equation (10), we need to specify the stochastic discount factor, $\Gamma_{i t+1}$. As Cochrane (2001) argues, all asset pricing models amount to different ways of connecting the stochastic discount factor to data. There are many possible structural or reduced-form parametrizations, expressing the stochastic discount factor as functions of state variables such as consumption growth, aggregate wealth proxies, or data-driven factors. Opting for a reduced-form specification, we specify $\Gamma_{i t}$ as a function of several firm-level characteristics

\footnotetext{
${ }^{7}$ In earlier versions of the paper, we use a more flexible function form and parameterize the adjustment cost function as $C\left(I_{i t}, K_{i t}\right)=\left(\sum_{m=2}^{M} \frac{1}{m} \alpha_{m}\left(\frac{I_{i t}}{K_{i t}}\right)^{m}\right) K_{i t}$, where $\alpha_{m}, m=2, \ldots, M$ are coefficients to be estimated and $M$ is a truncation parameter that sets the highest power of $\frac{I_{i t}}{K_{i t}}$ in the expansion. We follow Whited and $\mathrm{Wu}$ (2006) and set $M=3$. Although including the cubic term in the adjustment cost function does yield slightly better model performance (similar to the findings in Whited, 1998), we find that some adjustment cost parameter estimates are negative and insignificant. We therefore opt for a quadratic adjustment cost function throughout our empirical analysis. We are extremely grateful to an anonymous referee for suggesting us comparing different forms of the adjustment cost function.
} 
and institutional variables. ${ }^{8}$ We assume

$$
\begin{aligned}
& \Gamma_{i t}=l_{0}+l_{1} O W N_{i t}+l_{2} L N L A B O R_{i t}+l_{3} H I N D_{i t}+l_{4} N E R I_{i t}+l_{5} T L T D_{i t} \\
& +b O W N_{i t} \times L N L A B O R_{i t},
\end{aligned}
$$

Here $O W N_{i t}$ is a set of dummy variables that specify a firm's ownership identification; $L N L A B O R_{i t}$ is the natural logarithm of the number of employees, which captures firm size; $H I N D_{i t}$ is the industry Herfindahl index, which is the sum of squared firm market shares measured by sales in a given industry (based on the two-digit industry codes designated by NBS); $N E R I_{i t}$ measures the quality of institutions and financial development in the region in which a firm locates (see Section 4.3); and TLTD is the ratio of long-term liabilities to total assets, which captures the impact of financing decisions on corporate investment.

An ad hoc parameterization of the stochastic discount factor provides empirical flexibility. For example, we include $O W N$ as a set of determinants, which translates the potential effects of ownership on investment into differences in the stochastic discount factor across $O W N$. Several issues arise in this reduced-form specification of the stochastic discount factor. First, the parameterization in Equation (11) does not allow for an explicit error term, and hence the specification could be incorrect. We test this assumption using $J$-test statistics of overidentifying restrictions, which provide an important check on the model's validity. Second, the structural model provides no guidance as to which variables should be included in the parameterization of the stochastic discount factor. To address this issue, we start with the most general specification, and then drop variables that display low statistical significance, and examine the difference between the minimized GMM objective functions of the two

\footnotetext{
${ }^{8}$ One caveat with respect to our specification is that it does not model traditional risk factors such as $\beta$, book-to-market, and momentum, as the majority of our sample firms are not publicly listed. We defer a more general specification of $\Gamma_{i t}$ to Section 6.2, where we analyze the universe of listed firms in China. We are not particularly concerned about the omission of these factors here because (1) our estimations, as we will explain later, are based on three-year investment data (2003 to 2005), and thus our results are driven largely by cross-sectional variation rather than time-series variation; and (2) we include in the specification a rich set of firm-specific variables that likely pick up these traditional risk factors.
} 
models. The difference asymptotically follows a $\chi^{2}$ distribution with degrees of freedom equal to the number of variables dropped from the more general model. If a variable belongs in the parameterization of the stochastic discount factor, its omission should produce a low p-value. We use Whited and Wu's (2006) L-test to test these exclusion restrictions.

We estimate Equation (10), with $\Gamma_{i t+1}$ parameterized as in Equation (11), in first differences to eliminate possible fixed firm effects. We apply GMM to the moment conditions

$$
E_{t-1}\left[z_{i t-1} \otimes\left(e_{i t+1}-e_{i t}\right)\right]
$$

where $z_{i t-1}$ is a vector of instrumental variables known at time $t$, and $\otimes$ denotes the Kronecker product. Because this estimator is implemented in first differences, the procedure calls for using variables dated $t-2$ as instruments. We thus use as instruments the two-periodlagged variables that include all the variables that appear in our investment Euler equation and several firm-specific variables. To account for potential macroeconomic shocks, we also include time dummies.

\section{Data and Descriptive Statistics}

In this section we discuss our data sources and the construction of our samples. We next define the variables used in the empirical analysis and provide their summary statistics.

\subsection{Data Sources}

We primarily use a database developed and maintained by the National Bureau of Statistics of China to conduct our empirical analysis. The NBS data are in fact census data. The NBS surveys all industrial firms in China with sales above RMB5 million (approximately US\$735,000). The NBS database is constructed based on annual accounting briefing reports

filed by these industrial firms in China with the NBS. The database covers close to 190,000 firms in 37 2-digit manufacturing industries and from 31 provinces or province-equivalent 
municipal cities from 2000 to 2005 . The NBS database represents literally all of China's industrial value added and $22 \%$ of China's urban employment in $2005 .{ }^{9}$

The NBS designates every firm in the database a legal identification number and specifies its ownership type. Firms are classified into one of the following six primary ownership categories: SOEs, collective firms, private firms, mixed-ownership firms (mainly joint stock companies), foreign firms, and Hong Kong, Macao, and Taiwan invested firms (HK/TW firms). The NBS does not treat publicly listed companies in China separately. It is difficult to track these firms as their legal identification numbers are changed when they go public. But they all belong to the mixed ownership category. By 2005, there are about 1,400 publicly listed companies in China's two stock exchanges, of which only slightly over 800 are industrial firms.

The NBS database contains detailed information that allows us to construct variables required for GMM estimations of investment Euler equations. All monetary terms used in our empirical analysis are in 2000 constant Renminbi (RMB) Yuan.

In addition to using the NBS database, we also conduct our empirical analysis using the universe of China's listed companies in Section 6.2. The listed firms' financial data are retrieved from the CSMAR Financial Databases developed by Shenzhen GTA Information Technology Co. The sample period for this analysis is 1999 to 2005.

\subsection{Sampling}

To conduct GMM estimations, we need a balanced panel of firm-year observations. The NBS dataset, however, has several built-in weaknesses. First, the firms included in the NBS survey each year are not always the same. About $20 \%$ of firms enter or exit the database each year as a result of changes in their size classification or in their identification numbers due to mergers, acquisitions, bankruptcies, or restructuring. Although the original NBS database contains industrial firms with numbers ranging from 162,883 to 279,092 over 2000 to 2005,

\footnotetext{
${ }^{9} \mathrm{~A}$ few studies on China use this database. See, e.g., Li et al. (2009) and Cai and Liu (2009).
} 
only 40,217 of these firms appear every year. Second, because NBS chooses to include in the database any industrial firm with annual sales above RMB 5 million, many firms are fairly small. One may wonder whether those relatively small firms represent corporate China well. Third, the NBS dataset does not have information on capital expenditures or firm-level fixed asset investment. We thus have to compute fixed asset investment, $I_{i t}$, according to the investment accounting identity. However, not all the information required to calculate $I_{i t}$ is available for all firms in the data.

Given the above considerations, our sampling process includes in our sample those firms with data entries every year from 2000 to 2005. We delete firms with extreme variable values (1\% at both tails). Our final sample contains 36,103 firms from 2000 to 2005. In 2005 , these firms account for approximately $55 \%$ of total industrial value added and $12 \%$ of urban employment in China.

Table 1 reports the ownership and industry breakdowns of our sample firms. As shown in Panel A, SOEs, collective firms, mixed firms, private firms, HK/TW firms, and foreign firms respectively account for $13.29 \%, 14.09 \%, 20.93 \%, 21.54 \%, 15.18 \%$, and $14.97 \%$ of our sample. Panel B shows the industry breakdown. The textile (17), electrical machinery and equipment (39), ordinary machinery (35), nonmetal products (31), and raw chemical (26) industries are the five largest industries in our final sample, while petroleum and natural gas extraction (7) and ferrous mining (8) are the least covered industries. ${ }^{10}$ Table A3 presents the distribution by region. Guangdong, Zhejian, and Jiangsu are the three provinces with the largest numbers of firms, while Hainan, Tibet, Qinghai, and Ningxia have the fewest firms.

We note that our sampling process unavoidably introduces selection bias or survival bias. This concern is greatly mitigated however by the following considerations. First, most firms excluded from our sample are fairly small and young. Arguably, these firms do not capture the true picture of the Chinese industrial firms. Second, the ownership, industry, and region

\footnotetext{
${ }^{10}$ Numbers in brackets are the 2-digit industry codes designated by NBS.
} 
breakdowns of our sample firms are largely in line with those of the original NBS data. In addition, during the sampling process, we do not observe any significant cross-ownership, cross-industry, or cross-region patterns in the probability of an observation being dropped. Third, we conduct several robustness checks and find results very similar to those based on our final sample. ${ }^{11}$

\subsection{Variables}

We first construct six dummy variables to capture a firm's ownership status, respectively, $D^{S O E}, D^{\text {private }}, D^{\text {foreign }}, D^{H K / T W}, D^{\text {mixed }}$, and $D^{\text {collective }}$. These binary variables take the value of one if a firm falls into a corresponding ownership category and zero otherwise.

We measure firm $i$ 's output in year $t$ by its sales, Sale $i t$. Cost, $V C_{i t}$, is the sum of the costs of goods sold and administrative costs. We denote total assets as $T A_{i t}$. We divide both Sale $_{i t}$ and $V C_{i t}$ by total assets. The depreciation rate, $D R A T E_{i t}$, is computed as the ratio of $D E P_{i t}$ (current year depreciation) to beginning-of-year fixed assets, $K_{i t-1} \cdot{ }^{12}$ Cash flow, $C F K_{i t}$, is defined as earnings before depreciation and amortization. We retrieve total long-term liabilities, $T L T D_{i t}$, and current assets, $C A_{i t}$, from the NBS data. Besides the above variables, we use $I N V E N_{i t}$ to denote firm $i$ 's total inventories in year $t$. The firm's after tax income is defined as $I N C O M E_{i t}$, which is scaled by total sales. The effective tax rate, $T A X_{i t}$, is calculated as the ratio of total income tax to total before-tax profit. We use the natural logarithm of the number of employees, $L N L A B O R_{i t}$, to measure firm size. Except for $I N C O M E_{i t}, D R A T E_{i t}$, and $T A_{i t}$, all of the variables are scaled by total assets $\left(T A_{i t}\right)$. We also define firm age as $A G E_{i t}$. As discussed in Section 3.2, the industry-level Herfindahl index, $H I N D_{i t}$, is defined to capture the level of competitiveness of an industry.

\footnotetext{
${ }^{11}$ We conduct GMM estimations for several sub-samples. We first impose a size restriction and only include in our sample large-sized firms, that is, firms with total assets and total sales both above RMB 20 million. The estimation results are qualitatively similar. We also apply the estimation to the population of the publicly listed companies in China and again find qualitatively similar results (see Section 6.2). Thus, a selection bias, if any, likely affects the economic magnitude of our results but not their direction.

${ }^{12}$ We delete firms with DRATE $E_{i t}$ larger than one from our sample. About $0.4 \%$ of firms are thus dropped. Such a screening rule is consistent with our previously discussed guideline that firms with extreme variable values are excluded.
} 
China is a large and diversified country with significant regional differences in institutions and financial development (Demurger et al., 2002). China can be also described as a de facto federalism, involving a decentralized economic system in which each region can be considered an autonomous economic entity (Qian and Xu, 1993). Domestic financial markets in China are severely segmented - compared with developed markets, cross-region bank lending has been relatively rare (Boyreau-Debray and Wei, 2005). We use NERI, compiled by Fan and Wang (2004), to control for cross-regional differences in institutions. ${ }^{13}$

The NBS dataset contains information on firm-level fixed assets $\left(K_{i t}\right)$ and depreciations $\left(D E P_{i t}\right)$, which enables us to compute $I_{i t}$ by the investment accounting identity

$$
I_{i t}=K_{i t}-K_{i t-1}+D E P_{i t} .
$$

Since we do not have information on fixed assets in 1999, we can only compute $I_{i t}$ for the 2001 to 2005 period. To apply GMM estimations, we have to use variable values lagged by two periods as the instruments. We thus can only estimate investment Euler equations for 2003 to 2005. Panel A of Table 2 presents firms' investment rate $\left(I_{i t} / T A_{i t}\right)$ by ownership type from 2003 to 2005. Judged by firms' investment rate, private firms in China invest more than other types of firms in China, with average investment rate of $17.7 \%$. However, the numbers reported in Panel A of Table 2 might be misleading because they do not take into account the effects of firm size and investment opportunities. SOEs in China have a longer history and are usually larger than private firms and collective firms, but they do not necessarily have better investment opportunities.

To shed light on the extent to which corporate investment behavior in China varies across ownership, we regress the firm-level investment rate on ownership dummies and firm

\footnotetext{
${ }^{13}$ Fan and Wang (2004) examine the extent of marketization in each region by focusing on the following five factors: (1) the relation between the local government and local markets; (2) the significance of the nonstate sector in the local economy; (3) the development level of product markets; (4) the development level of factor markets; and (5) legal environment, law enforcement, and the development of market intermediaries. The weighted average of the scores on these five factors is computed and used to capture the market and legal conditions of China's diverse regions.
} 
size. Panel B of Table 2 reports the OLS regression results, where SOEs are used as the benchmark. In Model 1, only ownership dummies are included as the explanatory variables. The results verify the finding in Panel A - relative to SOEs, non-state sectors in China invest more, as all ownership dummies are significantly positive. In Model 2, we control for firm size by including $L N L A B O R$. We document similar results. Note that firm size enters the regression positively, implying that larger firms tend to invest more. One may therefore wonder whether ownership variables affect corporate investment via firm size. In model 3, we add to the regression interactions between ownership variables and firm size, $L N L A B O R$. We find that both the statistical and economic magnitudes of the ownership dummies are greatly attenuated. This finding suggests that after controlling for firm size, non-state sectors in China do not necessarily invest more. Using the investment rate to understand Chinese firms' investment behavior might thus be misleading.

In Table 3, we present the summary statistics of the variables used in our analysis. During 2001 to 2005, fixed asset investment on average accounts for $14.9 \%$ of total assets; the average depreciation rate $(D R A T E)$ for our sample firms is $17.2 \%$; and cash flow is about $3.4 \%$ of total assets $(C F K)$. The mean of $S T$, which is the ratio of total sales to total assets, is 1.274. The sales costs $(V C)$, which is defined as the total sales costs over total assets is $109.4 \%$. The profit rate (INCOME), defined as after-tax profit over total sales, has a mean of $2.7 \%$. The average firm age for our sample firms is 16.1 years, and an average firm has 500 employees (the mean of the natural logarithm of the number of employees is 5.35). In addition to the above variables, Table 3 also reports summary statistics for inventories over total assets $(I N V E N)$, income tax over total assets $(T A X)$, current assets over total assets $(C A)$, industry Herfindahl index $(H I N D)$, regional institutions $(N E R I)$, and longterm liabilities over total assets (TLTD). Their means are, respectively, $18.1 \%, 0.9 \%, 3.1 \%$, $0.011,6.29$, and $6.4 \%$. 


\section{The Effects of Ownership on Corporate Investment}

This section presents estimates of our GMM estimation for our sample consisting of 36,103 Chinese industrial firms. It also offers GMM estimates for several sub-samples.

\subsection{The Baseline Model}

We apply GMM estimations to various Euler equations. We start with the model specified in Equations (10) and (11), to examine the effect of ownership on corporate investment. As shown in Equation (11), the marginal effect of ownership on $\Gamma_{i t}$ is given by

$$
\frac{\partial \Gamma_{i t}}{\partial O W N_{i t}}=l_{1}+b L N L A B O R_{i t}
$$

In all of our estimations, SOEs are used as the benchmark, that is, we assume the coefficient of $D^{S O E}$ to be 0 . In Equation (14), the constant $l_{1}$ captures the effect of ownership variables on the stochastic discount factor that is unrelated to firm size, and $b \times L N L A B O R$ measures the effect of ownership on the stochastic discount fact via firm size. Plugging $\Gamma_{i t}$ given by Equation (11) into Equation (12) and using GMM estimations, we expect the estimated coefficients of $l_{1}$ and $b$ to be negative and positive, respectively.

We start with the most general specification of the stochastic discount factor, in which ownership dummies, their interactions with firm size, and various firm--, industry-, and region-level variables are used to parameterize $\Gamma_{i t}$. Together with the two unknown parameters in the production function and investment adjustment function ( $\mu$, and $\alpha$ ), we have a total of 16 parameters to estimate. ${ }^{14}$ Our instruments include all of the Euler equation variables lagged by two periods such as $S a l e_{i t-2}, V C_{i t-2}, D R A T E_{i t-2}$, and $I_{i t-2}$, as well as inventories $\left(I N V E N_{i t-2}\right)$, long-term liabilities $\left(T L T D_{i t-2}\right)$, current assets $\left(C A_{i t-2}\right)$, the tax rate $\left(T A X_{i t-2}\right)$, firm size $\left(L N L A B O R_{i t-2}\right)$, net income $\left(I N C O M E_{i t-2}\right)$, cash flow $\left(C F K_{i t-2}\right)$, firm age $\left(A G E_{i t-2}\right)$, industry-level Herfindahl index $\left(H I N D_{i t-2}\right)$, ownership

\footnotetext{
${ }^{14}$ Note that the coefficients of the SOE dummy and its interaction with $L N L A B O R$ have been set to zero.
} 
dummies, two time dummies (years 2003 and 2004), and finally the constant. There are in total 22 instruments.

Table 4 presents the GMM estimates. Column (1) reports estimates from the most general model, where the discount factor is specified according to Equation (11). ${ }^{15}$ Each subsequent column contains GMM estimates from a model in which the variables with the smallest $t$ statistics are dropped from the stochastic discount function. We examine the difference in the minimized GMM objective functions for the most general and for the subsequently more parsimonious models. Each of these differences will have a $\chi^{2}$ distribution with degrees of freedom equal to the number of variables excluded from the model. If a variable should be included, its omission should produce a small $p$-value.

Note that of the five models in Table 4, the J-tests of over-identifying restrictions do not reject these restrictions except for the model in Column (5). This finding is particularly important in light of the deterministic specification of Equation (11). If this equation were to have an error term, the covariance between its error term and the remainder of the left side of Equation (10) would be implicitly included in $e_{i t+1}$, and would violate the over-identifying restrictions (see Whited and $\mathrm{Wu}$ (2006) for details). The fact that the model in Column (5) fails to pass the J-test indicates that the interactions between ownership dummies and $L N L A B O R$ should be included in the discount factor function. The ownership variables also affect the stochastic discount factor via the firm size channel.

The results of the most general model, where firm size, ownership dummies, their interactions with firm size, the industry-level Herfindahl index (HIND), the regional institution variable $(N E R I)$, and the ratio of long-term liabilities to total assets (TLTD) are used to parameterize the discount factor, show that HIND, NERI, and TLTD are not statistically significant with TLTD having the smallest t-statistic. The results from the model without TLTD are reported in Column (2). Whited and Wu's (2006) L-test

\footnotetext{
${ }^{15}$ We actually start with discount factor functions that contain more firm-level variables than Equation (11) does. The majority of those model specifications are not statistically significant. Including more variables in the discount factor function also significantly increases the demand for instrument variables and reduces the stability of the estimation results.
} 
suggests that dropping TLTD should not affect the performance of the model. Column (3) reports the results from the model that also drops NERI. The result of the L-test of exclusion restrictions again suggests that $N E R I$ should not be included in the discount factor function. In Column (4), we report the GMM estimates from the model in which $H I N D$ is also excluded from the discount factor function, and Whited and Wu's (2006) L-test suggests that $H I N D$ should be included in the Euler equation model (the $p$-value of the L-test is 0.066). The model in Column (3) has the best overall performance. We thus treat this model as our benchmark model in the empirical analysis.

The GMM estimates reported in Table 4, especially those in Column (3), reveal several findings. The estimated coefficients of $D^{\text {private }}, D^{\text {collective }}, D^{\text {mixed }}, D^{\text {foreign }}$, and $D^{H K / T W}$ are all significantly negative, and the estimated coefficients of their interactions with $L N L A B O R$ are all significantly positive. Since the effect of ownership on the discount factors perceived by managers is given by Equation (14), we plug the sample mean of $L N L A B O R, 5.35$, and estimated coefficients back into this equation to compute the ownership effect. We find that everything else being equal, an average non-state firm has a discount factor that is smaller than that of an average SOE. That is, managers of non-state firms tend to perceive a lower implied discount factor. Equivalently, they perceive a higher implied return on capital. This finding applies to all models in Columns (1)-(4).

We also find that the measure of competitiveness, $H I N D$, is significantly negative, suggesting that firms in more competitive industries, as indicated by a lower level of $H I N D$, have a higher (lower) discount factor (discount rate). That is, firms in more competitive industries tend to adopt lower hurdle rates to make investment. This result is consistent with the analytical finding in Grenadier (1996, 2002) and Williams (1993) that firms in more competitive industries may speed up investment so that they can enjoy a first-mover advantage. The estimated coefficient of $L N L A B O R$ is significantly negative in all models, implying that larger firms tend to have a lower (higher) discount factor (implied return on capital) than smaller firms. Larger firms tend to be more cautious about corporate 
investment after controlling for investment opportunities, competition, and the effects of other firm-specific attributes.

We now examine the economic magnitude of the ownership effect according to the estimates reported in Column (3). We compute the effect of ownership on the implied return on capital using Equation (14). The mean of $L N L A B O R$ in our sample is 5.35. Now consider the case of the private firms. All else being equal, a private firm's effective discount factor is 9.4 percentage points lower than that of a typical SOE. ${ }^{16}$ Similarly, we can compute the magnitude of the ownership effect for mixed firms, collective firms, foreign firms, and HK/TW firms. Our computation indicates that the perceived or implied return on capital for collective firms, mixed firms, HK/TW firms, and foreign firms is approximately 11.4, 13, 11.9, and 10 percentage points higher than that of an average SOE.

As shown in Table 4, the adjustment cost parameter, $\alpha$, is positive and statistically significant. Nonetheless, understanding the economic magnitude of the adjustment cost parameters is difficult. The literature does not provide a convincing standard for comparison, especially in the case of China. In addition, our 3-year panel may not be long enough to identify the discount factor parameters and adjustment cost parameters at the same time. Furthermore, firms may react sluggishly to an investment, in which case a relatively short panel makes it difficult to obtain precise estimate of the adjustment cost parameter. A caution therefore should be taken on the magnitude of $\alpha$.

The results in Table 4 show that on average non-state firms in China are more cautious about corporate investment than are SOEs. Given that over-investment has been a widespread phenomenon and has concerned policy makers (see our discussion in Section 1), a more cautious attitude toward investment may work against over-investment and thus be value-enhancing. In this regard, we interpret the use of higher discount rates in making investment decisions as an indicator of more efficient investment. It is worth noting that

\footnotetext{
${ }^{16}$ The estimated coefficients of the private firm dummy and its interaction with $L N L A B O R$ are respectively -1.175 and 0.202 . The aggregate impact of the private firm dummy on the effective discount factor is thus $-1.175+0.202 \times 5.35=-0.094$.
} 
the higher discount rates that non-state firms use to discount future investment payoffs may reflect financing constraints. We believe that the higher discount rates perceived by nonstate firms are largely driven by institutional deficiencies. First, as shown in Table 4, the mixed firms also perceive higher discount rates. The majority of mixed firms are controlled by the state and can be viewed as de facto SOEs. Their access to external finance can thus be expected to be at least as good as that of the SOEs. In addition, all of our sample firms are above scale firms and have high visibility. In an unreported analysis, we find that there is no significant difference in firm leverage ratio by ownership. Finally, in Section 6, we analyze the privatized SOEs and the Chinese listed firms, which are less subject to external financing constraints, and find similar results. In sum, our evidence suggests that while the state-dominated financial system in China greatly favors SOEs, it is unlikely the driver of a positive $\theta$.

To better visualize the effect of ownership on corporate investment, we estimate the perceived discount rate for each firm by plugging the relevant variable values into the stochastic discount factor equation, according to the model specification in Column (3) of Table 4. We assume that the average discount rate for all firms in our sample is $10 \%$ over 2001 to $2005 .{ }^{17}$ This assumption allows us to estimate the value of the constant term $l_{0}$, which is 1.904 for our sample. Based on the estimated coefficients, we compute the investment-based discount rate for each firm-year observation. Because the discount rates are inferred from the estimated discount factor equation and are tied to firm characteristics, there are many outliers. To better understand how ownership affects the investment behavior of average Chinese firms, we eliminate observations with extreme discount rate values from our analysis. Specifically, for each year, we delete firms with discount rates smaller than the 1st percentile or larger than the 99th percentile. For the remaining firms, we calculate yearly averages. Figure 1 plots these yearly averages. The figure shows that on average the SOEs

\footnotetext{
${ }^{17}$ This assumption is an innocuous one. Using different average discount rates would change the magnitude of the inferred discount rates, but would not change the relative patterns in the dynamics of the inferred discount rates.
} 
have the lowest return on capital.

\subsection{The Industry Analysis}

Our analysis in Section 5.1 does not fully control for the potential effects of industries. Although we include the Herfindahl index at the two-digit industry level (HIND), HIND is arguably an imperfect measure of industry effects. In addition, we assume that the firms from different industries face the same profit function and cost adjustment function, and that the cross-sectional variation in their investment behavior is totally driven by firm-level discount factors. These assumptions are restrictive. To check whether the empirical evidence reported in Section 5.1 is sensitive to these assumptions, we conduct additional empirical analysis below. ${ }^{18}$

We apply GMM estimations to the five largest industries (by number of firms) in our sample. These industries are: textile $(2,738 ; 7.58 \%)$, raw chemical $(2,646 ; 7.33 \%)$, nonmetal products $(2,899 ; 8.03 \%)$, ordinary machinery $(2,763 ; 7.65 \%)$, and electrical machinery $(3,218$; $8.91 \%$ ), where the first number in parentheses refers to the number of unique firms in each industry and the second number refers to this industry's share of the full sample. These five industries together account for $40 \%$ of our sample. We estimate the model specified in Column (4) of Table 4 for each of these five industries and report the estimation results in Columns (1)-(5) of Table $5 .{ }^{19}$

The results from Table 5 reveal several findings. First, for each industry, the estimated coefficients of the ownership dummies and their interactions with $L N L A B O R$ have the expected signs and in most cases are statistically significant. We compute the ownership effects by plugging the estimated coefficients and the means of $L N L A B O R$ into Equation (14), and find that in all five industries the non-state firms' managerial perceived

\footnotetext{
${ }^{18}$ For this part of analysis, we do not include the two time dummies (years 2003 and 2004) as instruments because our GMM estimations fail to converge for several industries. The total number of instruments thus is 20 .

${ }^{19}$ Note that we do not estimate the benchmark model as reported in Column (3) of Table 4 because we do not want to include $H I N D$ in the discount factor function.
} 
discount rates are significantly greater than those of the SOEs. Second, the estimated parameters of the profit and cost adjustment functions are quite different across the five industries, suggesting that firms in different industries do indeed face different investment opportunities.

In Column (6), we estimate our investment Euler equation for the whole sample, in which we include the 37 2-digit industry dummies in the discount factor function $\Gamma_{i t}$. This specification directly controls for the industrial effects on the discount factor. Compared to models in Columns (1) to (5), this model assumes that firms from different industries face the same investment opportunities and hence share the same profit and cost functions. We use GMM to estimate the model. Besides the 20 instruments described before, we also include the industry dummies as instruments. The degrees of freedom is still 7 . The J-test shows that we cannot reject the hypothesis that the model is correctly specified. We are interested in the signs and significance levels of the ownership dummies and their interactions with $L N L A B O R$. After we include the industry dummies in $\Gamma_{i t}$, non-state firms still demonstrate distinct investment behavior. For example, plugging the estimated coefficients and the mean of $L N L A B O R$ into Equation (14), we find that all else being equal, an average private firm has an implied return on capital that is 12.1 percentage points higher than that of an average SOE. This magnitude is slightly larger than that reported in Table 4, where industry dummies are not included. Overall, the results in Table 5 show that the ownership effects identified earlier are robust to industry effects.

\subsection{Evidence from Domestic Firms}

Foreign firms and Hong Kong/Taiwan invested firms operating in China use financing channels different from domestic firms. Arguably, their investment decision making process may also differ from that of domestic firms. One may wonder whether pooling domestic firms and foreign firms leads to spurious results. To shed more light on how institutions affect Chinese firms' investment decisions, as a robustness check we apply GMM estimations to a 
sub-sample consisting of 25,220 domestic firms in each year from 2001 to 2005. We replicate the estimations in Table 4 and find qualitatively similar ownership effects. For brevity, we do not report these results in the text.

\section{Further Analysis}

To offer more direct cross-checks on our empirical results, we apply the same approach to another two samples of Chinese firms - the privatized SOEs (Section 6.1) and the universe of publicly listed firms in China (Section 6.2). Such analysis has several incremental advantages. First and foremost, both the privatized SOEs and the publicly listed firms in China are less subject to external financing constraints. Estimating these firms allows us to provide more clear-cut evidence on the extent of institutions on corporate investment. Second, estimating privatized SOEs allows us to study how a firm's investment behavior changes after institutions concerning the firm have been improved. Third, in the case of listed firms, they contain more publicly accessible information and the information is more transparent and plausibly more reliable, which allows us to construct more variables to capture the potential effects of institutions. Finally, the listed firms allow us to conduct GMM estimations over a relatively longer time period, i.e., 1999 to 2005.

\subsection{Estimating the Privatized Firms}

We first examine the partially privatized SOEs from 2003 to 2005. In 2003, there are 4,799 SOEs in our sample. 500 of them subsequently changed their ownership status to mixed, and 98 firms changed their ownership status to private. We expect the managers of those firms to use higher discount rates when investing after they have been privatized.

We create two dummies $M I X$ and Private, which take the value of 1 if an SOE becomes a mixed firm or a private firms in either 2004 or 2005, and 0 otherwise. We start with the 
most general model, in which the discount factor function is specified as below:

$$
\begin{aligned}
\Gamma_{i t}= & l_{0}+l_{1} M I X_{i t}+l_{2} \text { Private }_{i t}+l_{3} \text { LNLABOR }_{i t}+l_{4} \text { HIN }_{i t}+l_{5} N E R I_{i t} \\
& +l_{6} \text { TLTD }+b_{1} M I X_{i t} * \text { LNLABOR }_{i t}+b_{2} \text { Private }_{i t} * \text { LNLABOR }_{i t} .
\end{aligned}
$$

Applying the GMM estimation to Equations (10) and (15), we report the estimated coefficients in Column (1) of Table 6. The model passes the J-test and reveals several findings. First, the estimated coefficients of $M I X$ and its interaction with $L N L A B O R$ are statistically significant. However, the estimated coefficients of Private and its interaction with $L N L A B O R$ are not, which might be due to the fact that few firms changed their ownership status from SOE to private during 2003-2005. We thus exclude Private and its interaction with $L N L A B O R$ from the discount factor function $\Gamma_{i t}$ in Column (2) of Table 6. In Column (3), we further exclude $M I X \times L N L A B O R$. The results from the L- tests show that the model in Column (2) is correctly specified. The mean of $L N L A B O R$ for SOEs is 5.5, and the impact of $M I X$ on the effective discount factor is thus given by $l_{1}+b_{1} L N L A B O R$. Plugging estimates of $l_{1}$ and $b_{1}$ and the mean of $L N L A B O R$ into the formula, we find that all else being equal, a privatized firm has its discount factor decreased by 0.105 . Putting it in another way, its effective discount rate increases by roughly 10.5 percentage points.

Results reported in Column (2) of Table 6 yield several other interesting findings. The estimate on the measure of industrial competition $H I N D$ is significantly negative, suggesting that firms in more competitive industry tend to use lower discount rates. The estimates on NERI and TLTD are both negative and statistically significant, suggests that all else being equal SOEs located in regions with better institutions and more levered SOEs tend to use higher discount rates when investing.

However, it is worth pointing out that this part of analysis is subject to a potential sample selection bias. The same factors that lead to an SOE privatization may also affect this particular firm's investment decisions. Our estimation strategy cannot disentangle 
their impact from that of institutional improvement. The results from this part of analysis therefore should be taken with a caution.

\subsection{Estimating the Listed Firms in China}

In this subsection, we examine the universe of China's listed firms from 1999 to $2005{ }^{20}$ The listed firms' financial data are extracted from the CSMAR Financial Databases developed by Shenzhen GTA Information Technology Co. We obtain a sample of 5,977 firm-year observations for our sample period, which represents 1,009 unique listed firms in China. To make the estimation results comparable, we exclude firms in financial services and utilities. We also delete firms with extreme variable values (1\% at both tails). These filters leave us with a panel of 646 firms in each year from 1999 to 2005.

To better capture the effects of institutions, we construct a rich set of corporate governance variables and investigate how these variables affect the discount rates used by listed firms to make investment. We define $S O E$ as a binary variable that takes the value of 1 if a listed firm is controlled by either the central government or a local government and 0 otherwise. OUTSIDE is computed as the ratio of outside board members to total board members. We define PARENT as a binary variable with the value of 1 if a listed firm belongs to a group firm and 0 otherwise. TOPSHARE is the fraction of shares held by the ultimate controlling shareholder. $C E O C H A I R$ is a binary variable with the value of 1 if the CEO is also the board chairman. Some listed firms in China also have shares listed and traded in the Hong Kong Stock Exchange; these shares are labeled 'H' shares. Further, since late 1991, some listed firms have sold shares to foreign individuals and institutions; these shares are labeled ' $\mathrm{B}$ ' shares and are traded on the mainland Chinese stock exchanges in a market that is separate from regular shares termed 'A' shares. We construct a dummy variable $H B S H A R E$ that takes the value of 1 if a firm has $\mathrm{H}$ - or $\mathrm{B}$-shares traded by foreign investors and 0 otherwise. It has been argued that firms issuing either $\mathrm{H}-$ or $\mathrm{B}$-shares to

\footnotetext{
${ }^{20}$ We start with 1999 because Chinese listed firms' corporate governance variables are not available until 1999.
} 
foreign investors have a higher level of transparency and better overall corporate governance practice (see, e.g., Bai et al., 2004).

With the above corporate governance variables in hand, we parameterize the discount factor function $\Gamma_{i t}$ as follows:

$$
\begin{aligned}
\Gamma_{i t}= & l_{0}+l_{1} S_{\text {OOE }}+l_{2} L N L A B O R_{i t}+l_{3} \text { OUTSIDE }_{i t}+l_{4} C F K_{i t}+l_{5} H_{I N} D_{i t}+l_{6} \beta(16) \\
& +l_{7} \text { HBSHARE }_{i t}+l_{8} \text { TOPSHARE }+l_{9} \text { CEOCHAIR }+l_{10} \text { PARENT }+l_{11} B / M,
\end{aligned}
$$

where $\beta$ is computed annually by using the CAPM model to capture systematic risk; $\mathrm{B} / \mathrm{M}$ is the book-to-market ratio; LNLABOR, CFK and HIND are defined as in our earlier analysis.

We apply our GMM estimator to the listed firm sample and report the results in Table 7. As can be seen in Table 7, the J-test of over-identifying restrictions fails to reject the validity of this model. As for the parameter estimates, the estimated coefficient of the investment adjustment cost function $(\alpha)$ are is positive and significant at the $10 \%$ level. Notably, Table 7 reveals several interesting findings about the roles played by corporate governance variables. First, the estimated coefficient of $S O E$ is significantly positive at 0.158 . This suggests that all else being equal, an SOE's implied discount factor is approximately 15.8 percentage points higher than that of other listed firms.

Second, we find that other corporate governance variables have expected signs and are statistically significant in most cases. The listed firms with $\mathrm{H}-$ or $\mathrm{B}-$-shares traded by foreign investors tend to be more cautious about investment. These firms are audited by international accounting firms and hence are arguably more transparent compared to other listed firms in China. We also find that firms with more outside board members use higher discount rates in making investment decisions, suggesting that board independence affects Chinese firms' investment. Firms with more shares concentrated in the hands of controlling shareholders also have higher implied returns on capital. When the controlling shareholders 
own more shares, their interests are more aligned with those of the firm, which may lead to better decision making.

As for the other parameter estimates, we find that the estimated coefficient of $\beta$ is negative, but it is not significant. We also find that the estimated coefficient of the bookto-market ratio is positive and insignificant. The estimated coefficients of CFK and HIND are both insignificant. The effects of these variables on corporate investment may have been picked up by other firm-level variables.

To summarize, the estimation results based on China's listed firms generate consistent findings - all else being equal, non-state firms in China are more cautious about investment than state firms, and firms with better corporate governance (i.e., better institutions) are more cautious about investment.

\section{Conclusions}

In this paper, we use an investment Euler equation framework to assess the effects of institutions on Chinese firms' corporate investment decisions. We specify our investment Euler equation in such a way that variables measuring institutions are allow to affect the rate at which managers discount investment projects. The key insights of our Euler equation framework are that the optimal level of firm investment is reached by trading off the intertemporal costs and benefits of investment via an appropriate stochastic discount factor, and that the stochastic discount factor is related to a utility-maximizing manager's preference for risk taking. We apply GMM to estimate the parameters of our investment Euler equation and we infer managers' implied discount rates from these estimated parameters.

We apply our empirical approach to several samples of Chinese firms. Our first sample covers "above scale" Chinese industrial firms over the period 2001 to 2005. We document robust evidence that the discount rates managers of Chinese firms apply vary significantly across ownership types. All else being equal, non-state firms in China use a much higher 
discount rate to guiding their investment decisions than SOEs. We apply the same approach to another two firm samples, the privatized SOEs in China and the universe of listed firms in China. We provide evidence that an SOE uses a higher discount rate to invest after privatization and that firms with better corporate governance use a higher discount rate to make investment decisions.

Taking into account the fact that over-investment has been a widespread phenomenon in China and also the fact that higher discount rates used by non-state firms are not entirely due to the financing constraints faced by these firms, we interpret our empirical findings as evidence supporting the argument that improving institutions helps impede widespread over-investment and enhances firms' investment efficiency. Our analysis thus suggests that shifting capital from the state sector to the non-state sector is socially beneficial in China.

Our empirical findings have important policy implications. To cope with the adverse impact of the global economic downturn on the Chinese economy, the Chinese government has injected into the economy a large fiscal stimulus package. While this stimulus has greatly boosted fixed asset investment and helped China maintain an impressive GDP growth rate, our analysis shows that managing the allocation of capital to achieve more effective investment remains a large challenge, and that solving this problem requires fundamental improvement in China's institutions. 


\section{References}

[1] Acemoglu, D., Johnson, S., and J. Robinson, 2001. The colonial origins of comparative edevelopment: an empirical investigation. American Economic Review 91(5), 1369-1401.

[2] Allen, F., J. Qian, and M. Qian, 2005. Law, finance, and economic Ggrowth in China. Journal of Financial Economics, 77 (1), 57-116.

[3] Bai, C., Q. Liu, Z. Lu, F. Song, and J. Zhang, 2004. Corporate governance and firm valuations. Journal of Comparative Economices, 32(4), 599-616.

[4] Bai, C., C. Hsieh, and Y. Qian, 2006. The return to capital in China, Brookings Papers on Economic Activities, 61-88.

[5] Beck, T., A. Demirguc-Kunt, and R. Levine, 2003. Law, endownments, and finance. Journal of Financial Economics, 70(2):137-181.

[6] Bekaert, G., C. Harvey, C. Lundblad, 2005. Does Financial Liberalization Spur Growth. Journal of Financial Economics 77, 3-56.

[7] Boyreau-Debray, G., S. Wei, 2005. Pitfalls of a state dominated financial system: the case of China. NBER working paper.

[8] Brandt, L., and H. Li (2003). Bank discrimination in transition economies: ideology, information, or incentives? Journal of Comparative Economics, 31: 387-413.

[9] Cai, H., Q. Liu, 2009. Competition and coproate tax avoidance: evidence form Chinese industiral firms. The Economic Journal, 119, 764-795.

[10] Chirinko, R., H. Schaller, 2004. A revealed preference approach to understanding corporate governance probelms: evidence from Canada. Journal of Financial Economics, 74: 181-206.

[11] Claessens, S., L. Laeven, 2003. Financial development, property rights, and gorwth. Journal of Finance 58, 2401-2436.

[12] Cochrane, J., 2001. Asset Pricing. Princeton University Press. Princeton, New Jersey.

[13] Cull, R., L.C. Xu, 2005. Instituions, ownership, and finance: the determinants of prifit reinvestmetn among Chinese firms, Journal of Financial Economics, 77(1), 117-146.

[14] Demurger S., J.D. Sachs, W.T. Woo, S. Bao, and G. Chang, 2002. The relative contributions of location and preferential policies in China's regional development: being in the right place and having the right incentives. China Econonic Review, 13: 444-465.

[15] Dewenter, K., and P. Malatesta, 2001. State-owned and privately owned firms: an empirical analysis of profitability, leverage, and labor intensity, American Economic Review, Vol. 91, No.1: 320-334. 
[16] Dollar D., and S. Wei, 2007. Das (wasted) Kapital: firm ownership and investment efficiency in China. NBER Working Paper 13103.

[17] Fan, G., and X.L. Wang, 2004. NERI index of marketization of China's provinces. Economics Science Press (In Chinese).

[18] Farrell, D., U. Gersch, and E. Stephenson, 2006. How financial-system reform could benefit China? The McKisney Quarterly, 2006 special edition on Serving the new Chinese Economy, 41-55.

[19] Forbes, K., 2007. One cost of the Chilean capital controls: increased financial constraints for samller trade firms. Journal of International Economics, forthcoming.

[20] Gordon, R.H., and Wei Li, 2003. Government as a discriminating monopolist in the financial market: the case of China. Journal of Public Economics 87, 283-312.

[21] Grenadier, S., 1996. The strategic exercise of options: development cascades adn overbuilding in real estate markets. Journal of Finance, 51, 1653-1679.

[22] Grenadier, S., 2002. Option exercise games: an applicaiton to the equilibrium investment strategies of firms. Review of Financial Studies, 15(3), 691-721.

[23] Guiso, L., P. Sapiegza, L. Zingales, 2004. Does local financial development matter? Quarterly Journal of Economics, 119: 929-969.

[24] Hsieh C., and P. Klenow, 2007. Misallocation and manufacturing TFP in China and India. NBER Working Paper 13290.

[25] Huang, Y., 2003. Selling China: foreign direct investment during the reform era. The Cambridge University Press.

[26] Kang, Q., Q. Liu, and R. Qi, 2010. The Sarbane-Oxley Act and corporate investment: a structual assessment. Journal of Financial Economics, 96, 291-305.

[27] Kornai, J., 1980. The economics of shortage. Amsterdam: North-Holland.

[28] Levine, R., and S. Zervos, 1998. Stock market, banks, and economic growth. American Economic Review, Vol.88(3), 537-558.

[29] Li, K., H. Yue, L. Zhao, 2009, Ownership, institutions, and capital structure: evidence from China. Journal of Comparative Economics, 37, 471-490.

[30] Liu, L., T. Whited, and L. Zhang, 2009. Investment-based expected stock returns. Journal of Political Economy, 117, 1105-1139.

[31] Love, I., 2003. Financial development and financing constraints: International evidence from the structural investment model. Review of Financial Studies, Vol.16 (3), 765-791.

[32] Newey, W., K. West, 1987. Hypothesis testing with efficient method of moments estimation. International Economic Review, 28: 777-787. 
[33] Qian, Y., and C. Xu, 1993. The M-form Hierarchy and China's economic reform. European Economic Review, 31, 541-548.

[34] Rajan, R., and L. Zingales, 1998. Financial dependence and growth. American Economic Review, 88, 559-586.

5Journal of Economic Perspectives, 12 (4), 133-150.

[35] Whited, T., 1992. Debt, liquidity constraints, and coporate investment: evidence from panel data. Journal of Finance, 47, 1425-1460.

[36] Whited, T., 1998. Why do investment Euler equations fail? Journal of Business and Economic Statistics,16: 469-478.

[37] Whited, T., and G. Wu, 2006. Financing constraints risk. Review of Financial Studies, 19: 531-559.

[38] Williams, J., 1993. Equilibrium and options on real assets. Review of Financial Studies, $6,825-850$.

[39] Young, A., 2001. The razor's edge: distortion and incremental reform in the People's republic of China. Quarterly Journal of Economics.

[40] Zhang, L., 2005. The value premium. Journal of Finance, 60, 67-103. 


\section{Table 1 Ownership and Industry Breakdowns of Sample Firms}

The data source is a database compiled by the National Bureau of Statistics in China (NBS) that covers all industrial firms in China with total sales above RMB 5 million from 2000 to 2005. We delete the firms with extreme variable values (one percent at both tails), and obtain a balanced panel of 36,103 firms. Panel A reports the ownership breakdown of our sample firms, where SOE stands for state-owned enterprises; Collective stands for collective firms; Private refers to privately owned firms; Mixed refers to the joint-stock companies; Foreign stands for foreign firms operating in China; and HK/TW stands for the Hong Kong, Macao, or Taiwan invested firms operating in China. Panel B presents the distribution of our sample firms by the 2-digit industry codes designated by the NBS.

Panel A: by ownership

\begin{tabular}{lcc}
\hline \hline & \# of Firms & \% of the sample \\
\hline & & \\
SOE & 4,799 & 13.29 \\
Collective & 5,087 & 14.09 \\
Mixed & 7,557 & 20.93 \\
Private & 7,777 & 21.54 \\
HK/TW & 5,482 & 15.18 \\
Foreign & 5,401 & 14.97 \\
& & \\
Total & 36,103 & 100 \\
\hline
\end{tabular}


Table 1 continued

Panel B: by industry

\begin{tabular}{|c|c|c|c|}
\hline $\begin{array}{l}\text { Industry } \\
\text { Code }\end{array}$ & Industry & $\begin{array}{l}\text { \# of } \\
\text { firms }\end{array}$ & Percent \\
\hline 6 & Coal Mining & 479 & 1.33 \\
\hline 7 & Petroleum and Natural Gas Extraction & 10 & 0.03 \\
\hline 8 & Ferrous Mining & 61 & 0.17 \\
\hline 9 & Nonferrous Mining & 69 & 0.19 \\
\hline 10 & Nonmetal Mining & 193 & 0.53 \\
\hline 13 & Timber Logging & 1,465 & 4.06 \\
\hline 14 & Food Production & 697 & 1.93 \\
\hline 15 & Beverage & 538 & 1.49 \\
\hline 16 & Tobacco & 73 & 0.2 \\
\hline 17 & Textile & 2,738 & 7.58 \\
\hline 18 & Textile Wearing Apparel, Footwear and Caps & 1,410 & 3.91 \\
\hline 19 & Leather & 749 & 2.07 \\
\hline 20 & Timber & 377 & 1.04 \\
\hline 21 & Furniture & 347 & 0.96 \\
\hline 22 & Papermaking & 1,146 & 3.17 \\
\hline 23 & Printing & 888 & 2.46 \\
\hline 24 & Cultural & 465 & 1.29 \\
\hline 25 & Petroleum Processing & 201 & 0.56 \\
\hline 26 & Raw Chemical & 2,646 & 7.33 \\
\hline 27 & Medical & 839 & 2.32 \\
\hline 28 & Chemical Fiber & 172 & 0.48 \\
\hline 29 & Rubber & 528 & 1.46 \\
\hline 30 & Plastic & 1,609 & 4.46 \\
\hline 31 & Nonmetal Products & 2,899 & 8.03 \\
\hline 32 & Pressing Ferrous & 657 & 1.82 \\
\hline 33 & Pressing of Nonferrous & 545 & 1.51 \\
\hline 34 & Metal Products & 1,689 & 4.68 \\
\hline 35 & Ordinary Machinery & 2,763 & 7.65 \\
\hline 36 & Special Equipment & 1,284 & 3.56 \\
\hline 37 & Transport Equipment & 1,820 & 5.04 \\
\hline 39 & Electrical Machinery and Equipment & 3,218 & 8.91 \\
\hline \multirow[t]{2}{*}{40} & Communication Equipment, Computers and & & \\
\hline & Other Electronic Equipment & 701 & 1.94 \\
\hline \multirow[t]{2}{*}{41} & Measuring Instruments and Machinery for & & \\
\hline & Cultural Activity and Office Work & 818 & 2.27 \\
\hline 42 & Artwork and Other Manufacturing & 1,158 & 3.21 \\
\hline 44 & Electric Power and Heat Power & 85 & 0.24 \\
\hline 45 & Gas Production & 766 & 2.12 \\
\hline 46 & Water Production & 479 & 1.33 \\
\hline Total & & 36,103 & 100 \\
\hline
\end{tabular}




\section{Table 2 Corporate Investment Rate by Ownership}

The investment rate is the ratio of fixed asset investment $\left(I_{i t}\right)$ to total assets $\left(K_{i t}\right)$. Due to data limitation, we can only estimate investment Euler equation models from 2003 to 2005. We thus report corporate investment rates in these three years.

Panel A: Distribution of corporate investment rates by ownership

\begin{tabular}{lcccc}
\hline \hline & 2003 & 2004 & 2005 & average \\
\hline SOE & 0.105 & 0.086 & 0.097 & 0.096 \\
Collective & 0.155 & 0.139 & 0.146 & 0.148 \\
Mixed & 0.156 & 0.138 & 0.145 & 0.146 \\
Private & 0.196 & 0.173 & 0.166 & 0.177 \\
HK/TW & 0.150 & 0.128 & 0.137 & 0.138 \\
Foreign & 0.145 & 0.139 & 0.138 & 0.141 \\
\hline
\end{tabular}

Panel B: OLS regressions of investment rates on ownership and firm size, 2001-2005 The dependent variable is $(\mathrm{I} / \mathrm{K})_{\mathrm{it}}$, the coefficient of SOEs dummy is set to be zero. Firm size is measured by the natural $\log$ of the number of employees. t-statistics with robust standard errors reported in parentheses. ${ }^{*}, * *$, and $* * *$ represent the significance levels at the $10 \%, 5 \%$, and $1 \%$ respectively.

\begin{tabular}{|c|c|c|c|}
\hline & (1) & (2) & (3) \\
\hline $\mathrm{D}^{\text {private }}$ & $\begin{array}{c}0.0869 * * * \\
(54.78)\end{array}$ & $\begin{array}{c}0.0914 * * * \\
(57.28)\end{array}$ & $\begin{array}{c}0.0127^{*} \\
(1.65)\end{array}$ \\
\hline $\mathrm{D}^{\text {collective }}$ & $\begin{array}{c}0.0535^{* * * *} \\
(33.25)\end{array}$ & $\begin{array}{c}0.0578 * * * \\
(35.78)\end{array}$ & $\begin{array}{c}0.0582^{* * * *} \\
(7.58)\end{array}$ \\
\hline $\mathrm{D}^{\text {mixed }}$ & $\begin{array}{c}0.0515^{* * *} \\
(32.56)\end{array}$ & $\begin{array}{c}0.0495 * * * \\
(31.26)\end{array}$ & $\begin{array}{c}0.0593 * * * \\
(8.41)\end{array}$ \\
\hline $\mathrm{D}^{\text {foreign }}$ & $\begin{array}{c}0.0451^{* * * *} \\
(26.58)\end{array}$ & $\begin{array}{c}0.0461 * * * \\
(27.18)\end{array}$ & $\begin{array}{r}0.0024 \\
(0.31)\end{array}$ \\
\hline $\mathrm{D}^{\mathrm{HK} / \mathrm{TW}}$ & $\begin{array}{c}0.0441^{* * * *} \\
(26.73)\end{array}$ & $\begin{array}{c}0.0446^{* * *} \\
(27.18)\end{array}$ & $\begin{array}{c}-0.0028 \\
(-0.36)\end{array}$ \\
\hline LNLABOR & & $\begin{array}{c}0.0097 * * * \\
(23.71)\end{array}$ & $\begin{array}{c}0.0563 * * * \\
(6.37)\end{array}$ \\
\hline $\mathrm{D}^{\text {private }} *$ LNLABOR & & & $\begin{array}{c}0.0153^{* * * *} \\
(10.62)\end{array}$ \\
\hline $\mathrm{D}^{\text {collective }} *$ LNLABOR & & & $\begin{array}{l}-0.0004 \\
(-0.30)\end{array}$ \\
\hline $\mathrm{D}^{\text {mixed*} *}$ LNLABOR & & & $\begin{array}{l}-0.0016 \\
(-1.27)\end{array}$ \\
\hline $\mathrm{D}^{\text {foreign }} *$ LNLABOR & & & $\begin{array}{c}0.008 * * * \\
(5.76)\end{array}$ \\
\hline $\mathrm{D}^{\mathrm{HK} / \mathrm{TW}} * \mathrm{LNLABOR}$ & & & $\begin{array}{c}0.0087 * * * \\
(6.32)\end{array}$ \\
\hline Adj. R-squared & 0.0166 & 0.0197 & 0.0208 \\
\hline \# of obs. & 180,515 & 180,515 & 180,515 \\
\hline
\end{tabular}




\section{Table 3 Summary Statistics}

The table presents the summary statistics of the key variables used in our empirical analysis from 2001 to 2005 (year 2000 is not included because investment data for that year are not available). We drop from our sample the firms with extreme variable values (one percent at both tails). We obtain a panel with 36,103 firms in each year. The definition of variables can be found in the first column. Note that LNLABOR is the natural log of the number of the employees, NERI is a variable designed by Fan and Wang (2004) to examine the extent of marketization in each province in China, CFK is the ratio of cash flow to total assets, HIND is the Herfindahl index at the two-digit industry level, and finally, AGE captures firm age.

\begin{tabular}{|c|c|c|c|c|c|}
\hline $\begin{array}{l}\text { Variable } \\
\end{array}$ & Obs & Mean & Std. Dev. & Min & Max \\
\hline $\begin{array}{l}\text { Long term liabilities / } \\
\text { total assets (TLTD) }\end{array}$ & 180,515 & 0.064 & 0.121 & 0.000 & 0.726 \\
\hline $\begin{array}{l}\text { Cash flow / total assets } \\
\text { (CFK) }\end{array}$ & 180,515 & 0.034 & 0.132 & -0.469 & 0.950 \\
\hline $\begin{array}{l}\text { Depreciation Rate } \\
\text { (DRATE) }\end{array}$ & 180,515 & 0.172 & 0.250 & 0.000 & 0.700 \\
\hline $\begin{array}{l}\text { Total sales /total assets } \\
\text { (ST) }\end{array}$ & 180,515 & 1.274 & 1.037 & 0.060 & 9.525 \\
\hline $\begin{array}{l}\text { Inventories / total assets } \\
\text { (INVEN) }\end{array}$ & 180,515 & 0.181 & 0.141 & 0.000 & 0.696 \\
\hline $\begin{array}{l}\text { Income tax / total assets } \\
\text { (TAX) }\end{array}$ & 180,515 & 0.009 & 0.015 & 0.000 & 0.122 \\
\hline $\begin{array}{l}\text { Sales costs / total assets } \\
\text { (VC) }\end{array}$ & 180,515 & 1.094 & 0.965 & 0.038 & 8.447 \\
\hline $\begin{array}{l}\text { Current assets /total } \\
\text { assets (CA) }\end{array}$ & 180,515 & 0.031 & 0.024 & 0.000 & 0.182 \\
\hline $\begin{array}{l}\text { Profits/total sales } \\
\text { (INCOME) }\end{array}$ & 180,515 & 0.027 & 0.083 & -0.663 & 0.331 \\
\hline Investment Rate $\left(\mathrm{I}_{\mathrm{it}} / \mathrm{K}_{\mathrm{it}}\right)$ & 180,515 & 0.149 & 0.194 & 0.000 & 0.976 \\
\hline $\begin{array}{l}\text { Industry Herfindahl } \\
\text { index (HIND) }\end{array}$ & 180,515 & 0.011 & 0.015 & 0.001 & 0.486 \\
\hline Firm size (LNLABOR) & 180,515 & 5.354 & 1.138 & 0.000 & 11.903 \\
\hline LABOR & 180,515 & 500.4 & 2082.1 & 30 & 147,722 \\
\hline NERI & 180,515 & 6.294 & 1.583 & 3.910 & 9.740 \\
\hline Firm Age & 180,515 & 16.120 & 13.854 & 1 & 105 \\
\hline
\end{tabular}




\section{Table 4 GMM Estimates of Investment Euler Equations on the Full Sample}

We estimate investment Euler equations on a sample of industrial firms from a database maintained by the National Bureau of Statistics of China (NBS). Our sample contains 36,103 industrial firms from 2001 to 2005. Nonlinear GMM estimations are conducted on the model in first differences with twice lagged instruments. There are in total 22 instruments in our estimations. $\alpha$ is the adjustment cost parameter to be estimated, and $\mu$ is a mark-up. $D^{\text {private }}$, $\mathrm{D}^{\text {collective }}, \mathrm{D}^{\text {mixed }}, \mathrm{D}^{\text {foreign }}, \mathrm{D}^{\mathrm{HK} / \mathrm{TW}}$ and $\mathrm{D}^{\mathrm{SOE}}$ are dummy variables indicating a firm's ownership type. The estimated coefficients of $\mathrm{D}^{\mathrm{SOE}}$, and $\mathrm{D}^{\mathrm{SOE}} *$ LNLABOR are set to be zero. LNLABOR is the natural logarithm of the number of the employees, CFK is the ratio of cash flow to total assets; HIND measures the industry-level Herfindahl index; TLTD is the ratio of long-term liabilities to total assets. NERI is a variable designed by Fan and Wang (2004) to examine the extent of marketization in each province in China. Standard errors are reported in parentheses. The p-values of the J-Test and L-Test on model specification are reported in the last two rows. $*, * *$, and $* * *$ represent the significance levels at the $10 \%, 5 \%$, and $1 \%$ respectively. 


\begin{tabular}{|c|c|c|c|c|c|}
\hline & (1) & (2) & (3) & (4) & (5) \\
\hline \multirow[t]{2}{*}{$\alpha$} & $0.072 *$ & $0.059 * *$ & $0.057 * *$ & $0.057 * *$ & $0.111 *$ \\
\hline & $(0.041)$ & $(0.031)$ & $(0.026)$ & $(0.027)$ & $(0.061)$ \\
\hline \multirow[t]{2}{*}{$\mu$} & $1.011 * * *$ & $1.104 * * *$ & $1.102 * * *$ & $1.086^{* * *}$ & $1.022 * * *$ \\
\hline & $(0.055)$ & $(0.038)$ & $(0.036)$ & $(0.039)$ & $(0.019)$ \\
\hline \multirow[t]{2}{*}{$\mathrm{D}^{\text {private }}$} & $-0.979 * * *$ & $-1.098 * * *$ & $-1.175 * * *$ & $-1.068 * * *$ & $-0.307 * * *$ \\
\hline & $(0.202)$ & $(0.329)$ & $(0.177)$ & $(0.173)$ & $(0.059)$ \\
\hline \multirow[t]{2}{*}{$\mathrm{D}^{\text {collective }}$} & $-1.038 * * *$ & $-0.926 * * *$ & $-0.879 * * *$ & $-0.918 * * *$ & $-0.287 * * *$ \\
\hline & $(0.235)$ & $(0.225)$ & $(0.205)$ & $(0.193)$ & $(0.062)$ \\
\hline \multirow[t]{2}{*}{$\mathrm{D}^{\text {mixed }}$} & -0.476 & $-1.315^{* * *}$ & $-1.163 * * *$ & $-1.281 * * *$ & $-0.335 * * *$ \\
\hline & $(0.361)$ & $(0.326)$ & $(0.219)$ & $(0.193)$ & $(0.072)$ \\
\hline \multirow[t]{2}{*}{$D^{\text {foreign }}$} & $-0.852 * * *$ & $-1.129 * * *$ & $-1.085 * * *$ & $-0.968 * * *$ & $-0.241 * *$ \\
\hline & $(0.151)$ & $(0.137)$ & $(0.091)$ & $(0.101)$ & $(0.102)$ \\
\hline \multirow[t]{2}{*}{$\mathrm{D}^{\mathrm{HK} / \mathrm{TW}}$} & $-0.896 * * *$ & $-1.067 * * *$ & $-0.991 * * *$ & $-0.852 * * *$ & $-0.312 * * *$ \\
\hline & $(0.279)$ & $(0.232)$ & $(0.143)$ & $(0.125)$ & $(0.072)$ \\
\hline \multirow[t]{2}{*}{ LNLABOR } & $-0.143 * * *$ & $-0.159 * * *$ & $-0.157 * * *$ & $-0.171 * * *$ & $-0.098 * * *$ \\
\hline & $(0.023)$ & $(0.019)$ & $(0.011)$ & $(0.008)$ & $(0.012)$ \\
\hline \multirow[t]{2}{*}{$\mathrm{D}^{\text {private }} *$ LNLABOR } & $0.167 * * *$ & $0.179 * * *$ & $0.202 * * *$ & $0.174 * * *$ & \\
\hline & $(0.038)$ & $(0.057)$ & $(0.034)$ & $(0.034)$ & \\
\hline \multirow[t]{2}{*}{$\mathrm{D}^{\text {collective }} *$ LNLABOR } & $0.165 * * *$ & $0.135 * * *$ & $0.143 * * *$ & $0.135 * * *$ & \\
\hline & $(0.046)$ & $(0.046)$ & $(0.043)$ & $(0.041)$ & \\
\hline \multirow[t]{2}{*}{$\mathrm{D}^{\text {mixed}} *$ LNLABOR } & 0.068 & $0.207 * * *$ & $0.193 * * *$ & $0.202 * * *$ & \\
\hline & $(0.059)$ & $(0.050)$ & $(0.032)$ & $(0.029)$ & \\
\hline \multirow[t]{2}{*}{$\mathrm{D}^{\text {foreign }} *$ LNLABOR } & $0.152 * * *$ & $0.186^{* * *}$ & $0.184 * * *$ & $0.173 * * *$ & \\
\hline & $(0.024)$ & $(0.022)$ & $(0.021)$ & $(0.028)$ & \\
\hline \multirow[t]{2}{*}{$\mathrm{D}^{\mathrm{HK} / \mathrm{TW}} * \mathrm{LNLABOR}$} & $0.151 * * *$ & $0.167 * * *$ & $0.163 * * *$ & $0.149 * * *$ & \\
\hline & $(0.037)$ & $(0.029)$ & $(0.019)$ & $(0.021)$ & \\
\hline \multirow[t]{2}{*}{ HIND } & -1.275 & -1.076 & $-1.047 *$ & & \\
\hline & $(1.096)$ & $(0.661)$ & $(0.591)$ & & \\
\hline \multirow[t]{2}{*}{ NERI } & -0.021 & 0.002 & & & \\
\hline & $(0.015)$ & $(0.016)$ & & & \\
\hline \multirow[t]{2}{*}{ TLTD } & 0.048 & & & & \\
\hline & $(0.365)$ & & & & \\
\hline Chi-squared & 6.531 & 7.153 & 7.468 & 10.851 & 27.973 \\
\hline Degree of freedom & 6 & 7 & 8 & 9 & 14 \\
\hline J-Test & 0.366 & 0.413 & 0.487 & 0.286 & 0.014 \\
\hline L-Test & n.a. & 0.431 & 0.575 & 0.066 & 0.000 \\
\hline
\end{tabular}


Table 5 GMM Estimates of Investment Euler Equations: Controlling for Industries

We estimate investment Euler equation models on various Chinese industries for 2003-2005. We choose the industries with sizeable number of firms in our sample (see Table 1). Columns (1) - (5) report the estimation results for the textile (17), raw chemical (26), nonmetal products (31), ordinary machinery (35), and electrical machinery and equipments (39) industries, respectively. Column (6) reports the estimation results on the full sample, in which we include thirty-seven industry dummies into the discount factor function. GMM estimation is conducted on the model in first differences with twice lagged instruments. $\alpha$ is the adjustment cost parameter to be estimated, and $\mu$ is a mark-up. $\mathrm{D}^{\text {private }}, \mathrm{D}^{\text {collective }}, \mathrm{D}^{\text {mixed }}, \mathrm{D}^{\text {foreign }}, \mathrm{D}^{\mathrm{HK} / \mathrm{TW}}$ and $\mathrm{D}^{\mathrm{SOE}}$ are dummy variables indicating a firm's ownership type. The estimated coefficients of $\mathrm{D}^{\mathrm{SOE}}$, and $\mathrm{D}^{\mathrm{SOE} *} \mathrm{LNLABOR}$ are set to be zero. LNLABOR is the natural logarithm of the number of the employees. Standard errors are reported in parentheses. The p-values of the J-Test on model specification are reported in the last row. $* * *$, and $* * *$ represent the significance levels at the $10 \%, 5 \%$, and $1 \%$ respectively.

\begin{tabular}{|c|c|c|c|c|c|c|}
\hline & (1) Textile & $\begin{array}{l}\text { (2) Raw } \\
\text { Chemical }\end{array}$ & $\begin{array}{l}\text { (3)Nonmetal } \\
\text { Products }\end{array}$ & $\begin{array}{l}\text { (4)Ordinary } \\
\text { Machinery }\end{array}$ & $\begin{array}{l}\text { (5)Elec. } \\
\text { Machinery }\end{array}$ & $\begin{array}{l}\text { (6) Full } \\
\text { sample }\end{array}$ \\
\hline \multirow[t]{2}{*}{$\alpha$} & $0.072 *$ & 0.031 & 0.041 & 0.027 & $0.141^{*}$ & $0.045 * *$ \\
\hline & $(0.040)$ & $(0.087)$ & $(0.077)$ & $(0.041)$ & $(0.076)$ & $(0.022)$ \\
\hline \multirow[t]{2}{*}{$\mu$} & $1.241 * * *$ & $0.923 * * *$ & $1.076 * * *$ & $1.063 * * *$ & $1.004 * * *$ & $1.104 * * *$ \\
\hline & $(0.079)$ & $(0.110)$ & $(0.027)$ & $(0.039)$ & $(0.038)$ & $(0.027)$ \\
\hline \multirow[t]{2}{*}{$\mathrm{D}^{\text {private }}$} & $-0.826 * * *$ & $-1.055 * * *$ & $-1.121 * * *$ & $-1.011 * * *$ & $-1.470 * * *$ & $-0.854 * * *$ \\
\hline & $(0.167)$ & $(0.094)$ & $(0.254)$ & $(0.073)$ & $(0.378)$ & $(0.175)$ \\
\hline \multirow[t]{2}{*}{$\mathrm{D}^{\text {collective }}$} & $-1.027 * * *$ & $-1.061 * * *$ & $-1.122 * * *$ & $-0.766 * * *$ & $-1.059 * * *$ & $-0.935 * * *$ \\
\hline & $(0.115)$ & $(0.094)$ & $(0.221)$ & $(0.231)$ & $(0.242)$ & $(0.215)$ \\
\hline \multirow{2}{*}{$\mathrm{D}^{\text {mixed }}$} & $-1.048 * * *$ & $-0.833 * * *$ & $-0.805 * * *$ & $-0.847 * * *$ & -0.319 & $-1.158 * * *$ \\
\hline & $(0.117)$ & $(0.127)$ & $(0.196)$ & $(0.182)$ & $(0.473)$ & $(0.221)$ \\
\hline \multirow[t]{2}{*}{$\mathrm{D}^{\text {foreign }}$} & $-1.127 * * *$ & $-0.894 * * *$ & $-1.452 * * *$ & $-1.308 * * *$ & $-1.107 * * *$ & $-1.064 * * *$ \\
\hline & $(0.167)$ & $(0.267)$ & $(0.559)$ & $(0.295)$ & $(0.218)$ & $(0.186)$ \\
\hline \multirow[t]{2}{*}{$\mathrm{D}^{\mathrm{HK} / \mathrm{TW}}$} & $-0.777 * * *$ & $-1.567 * * *$ & -0.081 & $-0.979 * * *$ & -0.394 & $-0.962 * * *$ \\
\hline & $(0.243)$ & $(0.475)$ & $(0.501)$ & $(0.165)$ & $(0.532)$ & $(0.095)$ \\
\hline \multirow[t]{2}{*}{ LNLABOR } & $-0.132 * * *$ & $-0.155 * * *$ & $-0.147 * * *$ & $-0.175 * * *$ & $-0.187 * * *$ & $-0.145 * * *$ \\
\hline & $(0.008)$ & $(0.010)$ & $(0.007)$ & $(0.012)$ & $(0.017)$ & $(0.014)$ \\
\hline \multirow[t]{2}{*}{$\mathrm{D}^{\text {private }} *$ LNLABOR } & $0.097 * * *$ & $0.166^{* * *}$ & $0.166 * * *$ & $0.182 * * *$ & $0.288 * * *$ & $0.137 * * *$ \\
\hline & $(0.033)$ & $(0.024)$ & $(0.048)$ & $(0.021)$ & $(0.085)$ & $(0.039)$ \\
\hline \multirow[t]{2}{*}{$\mathrm{D}^{\text {collective }} *$ LNLABOR } & $0.139 * * *$ & $0.165 * * *$ & $0.167 * * *$ & $0.129 * * *$ & $0.190 * * *$ & $0.131 * * *$ \\
\hline & $(0.019)$ & $(0.021)$ & $(0.041)$ & $(0.040)$ & $(0.042)$ & $(0.047)$ \\
\hline \multirow[t]{2}{*}{$\mathrm{D}^{\text {mixed}} *$ LNLABOR } & $0.136^{* * *}$ & $0.121 * * *$ & $0.112 * * *$ & $0.136^{* * *}$ & 0.051 & $0.170 * * *$ \\
\hline & $(0.020)$ & $(0.022)$ & $(0.034)$ & $(0.031)$ & $(0.085)$ & $(0.032))$ \\
\hline \multirow[t]{2}{*}{$\mathrm{D}^{\text {foreign }} *$ LNLABOR } & $0.156^{* * *}$ & $0.133 * *$ & $0.241 * *$ & $0.224 * * *$ & $0.209 * * *$ & $0.168 * * *$ \\
\hline & $(0.035)$ & $(0.062)$ & $(0.112)$ & $(0.055)$ & $(0.038)$ & $(0.021)$ \\
\hline \multirow[t]{2}{*}{$\mathrm{D}^{\mathrm{HK} / \mathrm{TW}} * \mathrm{LNLABOR}$} & $0.088 *$ & $0.271 * * *$ & -0.041 & $0.153 * * *$ & 0.072 & $0.130 * * *$ \\
\hline & $(0.051)$ & $(0.094)$ & $(0.109)$ & $(0.045)$ & $(0.091)$ & $(0.029)$ \\
\hline$\#$ of firms $(\%$ of full & 2,738 & 2,646 & 2,899 & 2,763 & 3,218 & 36,103 \\
\hline sample) & $(7.6 \%)$ & $(7.3 \%)$ & $(8.0 \%)$ & $(7.7 \%)$ & $(8.9 \%)$ & $(100 \%)$ \\
\hline Chi-squared & 4.903 & 7.236 & 5.973 & 12.585 & 3.247 & 5.925 \\
\hline Degree of freedom & 7 & 7 & 7 & 7 & 7 & 7 \\
\hline J-Test & 0.672 & 0.405 & 0.543 & 0.083 & 0.861 & 0.549 \\
\hline
\end{tabular}




\section{Table 6 GMM Estimates of Investment Euler Equations on the Privatized SOEs}

We estimate the investment Euler equation models over a sub-sample of firms that were privatized during the 2003-2005 period. We start with 4,799 state-owned enterprises (SOEs) in 2003. 500 firms changed their ownership status to mixed (joint stock); and $\mathbf{9 8}$ firms changed their ownership status to private either in 2004 or 2005 . We create two dummies variables MIX and Private, both of which take the value of 1 if an SOE's status is either a mixed or private firm in that year. Nonlinear GMM estimation is conducted on the model in first differences with twice lagged instruments. There are in total 20 instruments in our estimations. $\alpha$ is the are adjustment cost parameter to be estimated, and $\mu$ is a mark-up. LNLABOR is the natural logarithm of the number of the employees; HIND measures the industry-level Hirfindahl index; NERI is a variable designed by Fan and Wang (2004) to examine the extent of marketization in each province in China. TLTD is the ratio long-term liabilities to total assets. Standard errors are reported in parentheses. The p-values of the JTest and L-Test on model specification are reported in the last two rows. *,**, and $* * *$ represent the significance levels at the $10 \%, 5 \%$, and $1 \%$ respectively.

\begin{tabular}{clll}
\hline \hline & $(1)$ & $(2)$ & $(3)$ \\
\hline$\mu$ & 0.051 & 0.057 & 0.055 \\
& $(0.073)$ & $(0.041)$ & $(0.064)$ \\
MIX & $1.110^{* * *}$ & $1.091^{* * *}$ & $1.093^{* * *}$ \\
& $(0.051)$ & $(0.061)$ & $(0.043)$ \\
Private & $-0.344^{* *}$ & $-0.495^{* *}$ & $-0.061^{* * *}$ \\
& $(0.166)$ & $(0.243)$ & $(0.018)$ \\
LNLABOR & -1.138 & & \\
& $(1.672)$ & & \\
MIX*LNLABOR & $-0.039^{* *}$ & $-0.031^{* *}$ & $-0.033^{*}$ \\
& $(0.017)$ & $(0.018)$ & $(0.015)$ \\
Private*LNLABOR & $\left(0.056^{* *}\right.$ & $0.071^{* * *}$ & \\
& 0.231 & $(0.023)$ & \\
HIND & $(0.465)$ & & \\
NERI & $-1.579^{*}$ & $-2.032^{* * *}$ & $-1.844^{* * *}$ \\
& $(0.921)$ & $(0.781)$ & $(0.675)$ \\
TLTD & $-0.112^{* * *}$ & $-0.118^{* * *}$ & $-0.117 * * *$ \\
& $(0.012)$ & $(0.012)$ & $(0.012)$ \\
& $-0.473^{* *}$ & $-0.516^{* * *}$ & $-0.478^{* * *}$ \\
Chi-squared & $(0.222)$ & $(0.159)$ & $(0.162)$ \\
Degree of freedom & 13.006 & 15.384 & 18.527 \\
J-Test & 10 & 12 & 13 \\
L-Test & 0.223 & 0.221 & 0.139 \\
& n.a. & 0.305 & 0.076 \\
& & &
\end{tabular}




\section{Table 7 GMM Estimates of Investment Euler Equation on the Listed Firms, 1999 to 2005}

We estimate the investment Euler equation model against another firm population --- the universe of China's listed firms. We exclude financial firms and firms with missing variables, and obtain a balanced sample with 646 listed firms. We construct several corporate governance variables to capture the impact of institutions on the discount factor perceived by firm managers. The detailed definition is in the first column of the table. LNLABOR is the natural log of the number of the employees, $\mathrm{H}$ - and B- dummy specifies whether a firm has shares issued to and traded by foreign investors. CFK is the ratio of cash flow to total assets; HIND measures the industry-level Hirfindahl index; $\mathrm{B} / \mathrm{M}$ refers to book to market ratio. Standard errors are reported in parentheses. The p-value of the J-Test on the model specification is reported in the last row.

$* * *, * *$, and $*$ represent significance at $1 \%, 5 \%$, and $10 \%$ respectively.

\begin{tabular}{|c|c|}
\hline & GMM estimated coefficients \\
\hline \multirow[t]{2}{*}{$\alpha$} & $0.091 *$ \\
\hline & $(0.047)$ \\
\hline \multirow[t]{2}{*}{$\mu$} & $1.119 * * *$ \\
\hline & $(0.161)$ \\
\hline \multirow[t]{2}{*}{ SOE dummy } & $0.158 * * *$ \\
\hline & $(0.053)$ \\
\hline \multirow[t]{2}{*}{ H- or B- share dummy } & $-0.502 * *$ \\
\hline & $(0.218)$ \\
\hline \multirow[t]{2}{*}{ Is CEO also the Board Chairman? } & -0.035 \\
\hline & $(0.036)$ \\
\hline \multirow[t]{2}{*}{ Percentage of Shares held by controlling shareholder } & $-1.361 * *$ \\
\hline & $(0.593)$ \\
\hline \multirow[t]{2}{*}{ Outside board members / total board members } & $-1.001 *$ \\
\hline & $(0.517)$ \\
\hline \multirow[t]{2}{*}{ Is the listed firm one part of a group? } & 0.051 \\
\hline & $(0.047)$ \\
\hline \multirow[t]{2}{*}{ LNLABOR } & $-0.112 * * *$ \\
\hline & $(0.029)$ \\
\hline \multirow[t]{2}{*}{ CFK } & 0.081 \\
\hline & $(0.075)$ \\
\hline \multirow[t]{2}{*}{ HIND } & 0.040 \\
\hline & $(0.037)$ \\
\hline \multirow[t]{2}{*}{$\beta-$ measure of systematic risk } & -0.306 \\
\hline & $(0.521)$ \\
\hline \multirow[t]{2}{*}{$\mathrm{B} / \mathrm{M}$} & 0.401 \\
\hline & $(0.432)$ \\
\hline Chi-squared & 10.302 \\
\hline J-Test & 0.142 \\
\hline
\end{tabular}


Table A1 GDP, Fixed Asset Investment, and FDI in China 1990-2005

Source: China Statistical Yearbook

Exchange rate: 1 US\$ = RMB 8.026

\begin{tabular}{cccccc}
\hline \hline Year & $\begin{array}{c}\text { Gross } \\
\text { Domestic } \\
\text { Product } \\
\text { (RMB bn) }\end{array}$ & $\begin{array}{c}\text { Fixed asset } \\
\text { investment } \\
(\text { RMB bn) }\end{array}$ & $\begin{array}{c}\text { Percent of } \\
\text { GDP }\end{array}$ & $\begin{array}{c}\text { Foreign } \\
\text { Direct } \\
\text { Investments } \\
\text { (USD bn) }\end{array}$ & $\begin{array}{c}\text { Percent of } \\
\text { GDP }\end{array}$ \\
\hline 1990 & 1871.8 & 451.7 & $24.13 \%$ & 3.49 & $1.50 \%$ \\
1991 & 2182.6 & 559.5 & $25.63 \%$ & 4.37 & $1.61 \%$ \\
1992 & 2693.7 & 808.0 & $30.00 \%$ & 11.01 & $3.28 \%$ \\
1993 & 3526.0 & 1307.2 & $37.07 \%$ & 27.52 & $6.26 \%$ \\
1994 & 4810.9 & 1704.3 & $35.43 \%$ & 33.77 & $5.63 \%$ \\
1995 & 5981.1 & 2001.9 & $33.47 \%$ & 37.52 & $5.03 \%$ \\
1996 & 7014.3 & 2291.4 & $32.67 \%$ & 41.73 & $4.77 \%$ \\
1997 & 7765.3 & 2494.1 & $32.12 \%$ & 45.26 & $4.68 \%$ \\
1998 & 8302.4 & 2840.6 & $34.21 \%$ & 45.46 & $4.39 \%$ \\
1999 & 8818.9 & 2985.5 & $33.85 \%$ & 40.32 & $3.67 \%$ \\
2000 & 9800.1 & 3291.8 & $33.59 \%$ & 40.72 & $3.33 \%$ \\
2001 & 10806.8 & 3721.4 & $34.44 \%$ & 46.88 & $3.48 \%$ \\
2002 & 11909.6 & 4349.9 & $36.52 \%$ & 52.74 & $3.55 \%$ \\
2003 & 13517.4 & 5556.7 & $41.11 \%$ & 53.51 & $3.18 \%$ \\
2004 & 15958.7 & 7047.7 & $44.16 \%$ & 60.63 & $3.05 \%$ \\
2005 & 18395.6 & 8877.4 & $48.26 \%$ & 60.33 & $2.63 \%$ \\
\hline
\end{tabular}


Table A2 Fixed Asset Investment by Ownership 2000-2005

Source: China Statistical Yearbook

Unit: RMB bn

Fixed Asset Investment

\begin{tabular}{|c|c|c|c|c|c|c|}
\hline & 2000 & 2001 & 2002 & 2003 & 2004 & 2005 \\
\hline \multirow[t]{2}{*}{ SOE } & 1650.4 & 1760.7 & 1887.7 & 2166.1 & 2502.8 & 2966.7 \\
\hline & $50.14 \%$ & $47.31 \%$ & $43.40 \%$ & $38.98 \%$ & $35.51 \%$ & $33.42 \%$ \\
\hline \multirow[t]{2}{*}{ Collective } & 489.6 & 537.3 & 612.6 & 819.8 & 1018.3 & 1219.9 \\
\hline & $14.87 \%$ & $14.44 \%$ & $14.08 \%$ & $14.75 \%$ & $14.45 \%$ & $13.74 \%$ \\
\hline \multirow[t]{2}{*}{ Mixed } & 406.2 & 566.4 & 832.9 & 1273.4 & 1769.8 & 2353.6 \\
\hline & $12.34 \%$ & $15.22 \%$ & $19.15 \%$ & $22.92 \%$ & $25.11 \%$ & $26.51 \%$ \\
\hline \multirow[t]{2}{*}{ Private } & 470.9 & 542.9 & 651.9 & 772.0 & 988.1 & 1389.1 \\
\hline & $14.31 \%$ & $14.59 \%$ & $14.99 \%$ & $13.89 \%$ & $14.02 \%$ & $15.65 \%$ \\
\hline \multirow[t]{2}{*}{ HK/TW } & 129.3 & 158.3 & 176.5 & 237.5 & 311.4 & 376.7 \\
\hline & $3.93 \%$ & $4.25 \%$ & $4.06 \%$ & $4.27 \%$ & $4.42 \%$ & $4.24 \%$ \\
\hline \multirow[t]{2}{*}{ Foreign } & 131.3 & 141.5 & 168.5 & 253.4 & 385.4 & 465.7 \\
\hline & $3.99 \%$ & $3.80 \%$ & $3.87 \%$ & $4.56 \%$ & $5.47 \%$ & $5.25 \%$ \\
\hline \multirow[t]{2}{*}{ Others } & 13.9 & 14.2 & 19.8 & 34.6 & 72.1 & 105.7 \\
\hline & $0.42 \%$ & $0.38 \%$ & $0.46 \%$ & $0.62 \%$ & $1.02 \%$ & $1.19 \%$ \\
\hline \multirow[t]{2}{*}{ Total } & 3291.8 & 3721.3 & 4349.9 & 5556.7 & 7047.7 & 8877.4 \\
\hline & $100 \%$ & $100 \%$ & $100 \%$ & $100 \%$ & $100 \%$ & $100 \%$ \\
\hline
\end{tabular}


Table A3 The Breakdown of Sample Firms by Region

\begin{tabular}{|c|c|c|c|}
\hline Code & Region & \# of firms & Percent \\
\hline 11 & Beijing & 993 & 2.75 \\
\hline 12 & Tianjin & 936 & 2.59 \\
\hline 13 & Hebei & 1,337 & 3.7 \\
\hline 14 & Shanxi & 511 & 1.42 \\
\hline 15 & Inner Mongolia & 292 & 0.81 \\
\hline 21 & Liaoning & 1,352 & 3.74 \\
\hline 22 & Jilin & 337 & 0.93 \\
\hline 23 & Heilongjiang & 357 & 0.99 \\
\hline 31 & Shanghai & 2,664 & 7.38 \\
\hline 32 & Jiangsu & 4,911 & 13.6 \\
\hline 33 & Zhejiang & 5,399 & 14.95 \\
\hline 34 & Anhui & 649 & 1.8 \\
\hline 35 & Fujian & 2,254 & 6.24 \\
\hline 36 & Jiangxi & 284 & 0.79 \\
\hline 37 & Shandong & 2,561 & 7.09 \\
\hline 41 & Henan & 1,313 & 3.64 \\
\hline 42 & Hubei & 590 & 1.63 \\
\hline 43 & Hunan & 364 & 1.01 \\
\hline 44 & Guangdong & 4,721 & 13.08 \\
\hline 45 & Guangxi & 488 & 1.35 \\
\hline 46 & Hainan & 100 & 0.28 \\
\hline 50 & Chongqing+Sichuan & 1,666 & 4.61 \\
\hline 52 & Guizhou & 403 & 1.12 \\
\hline 53 & Yunnan & 537 & 1.49 \\
\hline 54 & Tibet+Qinghai + Ningxia & 121 & 0.34 \\
\hline 61 & Shaanxi & 502 & 1.39 \\
\hline 62 & Gansu & 235 & 0.65 \\
\hline 65 & Xinjiang & 226 & 0.63 \\
\hline Total & & 36,103 & 100 \\
\hline
\end{tabular}


Figure 1 The Investment-Implied Return on Captial By Ownership: 2001-2005

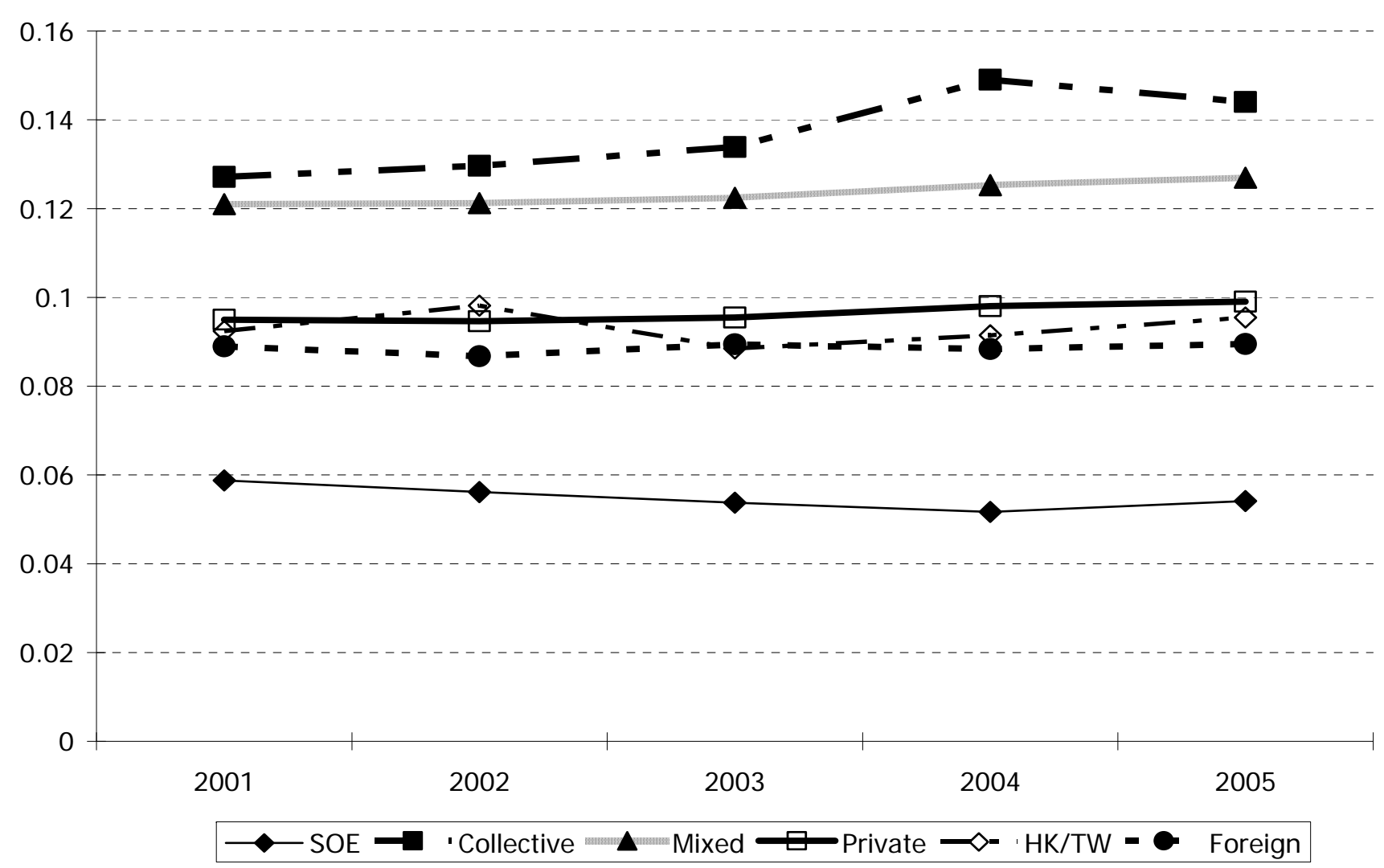

Note: We plug the variable values for each firm into the estimated discount factor function as specified in Model 3 of Table 4 (the benchmark model). We make an assumption that the average discount rate for all of the firms in our sample is $10 \%$. We thus back out the value of the intercept in the discount factor function, 1.904. We then compute the investment-implied discount rate for each firm in each year. We aggregate those firm-year observations by ownership and year. 